\title{
In-Situ Monitoring of Xenobiotics using Genetically Engineered Whole-Cell-Based Microbial Biosensors: Recent Advances and Outlook
}

Syed Azmal Ali ( $\sim$ alisyedazmal@gmail.com)

National Dairy Research Institute https://orcid.org/0000-0003-3024-9379

Deepti Mittal

National Dairy Research Institute

Gurjeet Kaur

University of New South Wales

Research Article

Keywords: Bacteria, Environmental contaminants, Genetically engineered, Heavy metals, Modified plasmids, Synthetic biology, Whole-cell microbial biosensor

Posted Date: February 22nd, 2021

DOI: https://doi.org/10.21203/rs.3.rs-264683/v1

License: @) (i) This work is licensed under a Creative Commons Attribution 4.0 International License. Read Full License

Version of Record: A version of this preprint was published at World Journal of Microbiology and Biotechnology on April 12th, 2021. See the published version at https://doi.org/10.1007/s11274-021-03024-3. 


\section{Abstract}

Industrialisation, directly or indirectly, exposes humans to various xenobiotics. The increased magnitude of chemical pesticides and toxic heavy metals in the environment, as well as their intrusion into the food chain, seriously threatens human health. Therefore, the surveillance of xenobiotics is crucial for social safety and security. Online investigation by traditional methods is not sufficient for the detection and identification of such compounds because of the high costs and their complexity. Advancement in the field of genetic engineering provides a potential opportunity to use genetically modified microorganisms. In this regard, whole-cell-based microbial biosensors (WCBMB) represent an essential tool that couples genetically engineered organisms with an operator/promoter derived from a heavy metal-resistant operon combined with a regulatory protein in the gene circuit. The plasmid controls the expression of the reporter gene, such as gfp, luc, lux and lacZ, to an inducible gene promoter and has been widely applied to assay toxicity and bioavailability. This review summarises the recent trends in the development and application of microbial biosensors and the use of mobile genes for biomedical and environmental safety concerns.

\section{Introduction}

The xenobiotic is a chemical substance found within an organism that is not naturally produced or expected to be present within the organism. It includes substances that are present in much higher concentrations than are usual. With this definition, the excessive industrialisation and urbanisation in the past few decades have resulted in a drastic increase in the rate of xenobiotic compounds being released into the environment, with long-term impacts on nutrient cycling. The effluent released from industries contain a wide range of environmental compounds such as heavy metals, with various health and environmental hazards (Gursahani et al. 2011). Heavy metals, including cadmium $(\mathrm{Cd})$, lead $(\mathrm{Pb})$, mercury $(\mathrm{Hg})$, arsenic $(\mathrm{As})$, among others are essential constituents of xenobiotics and are being extensively used at industrial levels (Gueu et al. 2007; Karbassi et al. 2008). The likelihood of these heavy metals bioaccumulating in different ecological levels poses a severe thread to biological systems (i.e. organismal organ systems) (Singh et al. 2017). According to the Agency for Toxic Substances and Disease Registry Reports (ATSDR), most of the aforementioned heavy metals are highly hazardous (https://www.atsdr.cdc.gov/spl/previous/07list.html).

Many xenobiotics either degrade slowly or are highly resistant to degradation and therefore remain in the environment for an extended period of time. Several different reasons are responsible for the slow degradation of xenobiotics in the natural environment. The foremost is unfavourable physicochemical conditions such as temperature, $\mathrm{pH}$, redox potential, oxygen concentration, and others, including nutrient limitation and auxiliary organic growth substrates (Bachmann et al., 1988) and various substrates such as solubility or predation (Swindoll et al., 1988). On the other hand, the incapacity of microorganisms present in the leading contaminant site to actively metabolise pollutants leads to their persistence in the environment for a more extended time (Katarína et al., 2018). This affects human health by damaging various organ systems (Singh et al. 2017). In this regard, environmental toxicology allows to study the adverse effects of anthropogenic and naturally occurring stressors, both qualitatively and quantitatively (Pranjali et al. 2012). There are several tools available that involve the quantification of xenobiotics, such as gas chromatography-mass spectroscopy (GC-MS) or high-performance liquid chromatography (HPLC). However, these techniques are likely to overestimate the risks as only a part of the total concentration of the pollutant will affect living organisms; specifically, the bioavailable part cannot be determined (Xuemei Liu et al. 2010). Other analytical techniques, such as inductively-coupled plasma mass spectrometry (ICP-MS), inductively-coupled plasma atomic electron spectrometry (ICP/AES), use strong acids during sample digestion, which themselves are pollutants, thereby making it difficult to distinguish between bioavailable and nonbioavailable fractions (Branco et al. 2013). In this sense, it is imperative to develop a practical, efficient and inexpensive method for actively monitoring and determining the concentrations of bioavailable constituents of xenobiotics in the environment. This review therefore focuses on the current knowledge for the detection of heavy metals and xenobiotics using whole-cell-based microbial biosensors (WCBMB).

The selective and sensitive assays were developed to evaluate the real exposure risk scenario of specific pollutants. One of the promising molecular-based tools is the use of whole-cell-based microbial biosensors (WCBMB) that possess considerable value in monitoring environmental contaminants (Ron E 2007). Microbes are considered excellent biosensing components for the construction of a biosensor to detect the bioavailable portion of a pollutant. Moreover, they are cost-effective, have a long lifespan and can survive in an array of suitable $\mathrm{pH}$ and temperature values, which significantly facilitates the improvement of the product (Mulchandani et al. 1998). Microbial biosensors might represent the most reliable and sensitive detection technology and can be used without expensive instruments and sophisticated skills. Despite the early prediction of microbial biosensors, there is still a large gap in the understanding and modernisation

Page 2/32 
of the technology. However, several genotoxicity tests have been developed, such as the Umu-Chromotest, the Ames test and the SOS Chromo test, but only the Umu-Chromotest was proved to be reliable, sensitive and reproducible in terms of assessing environmental genotoxicity (Oda et al. 1985) and was certified according to ISO standardisation (ISO 13829). Microbial biosensor research has focused on three significant applications. First, bacterial monitoring for competition ability and survival (Abby et al. 2003), second, tracking of xenobiotic-sensing or -degrading bacteria for complex environmental samples (Boldt et al. 2004), third, monitoring the degrees of specific environmental pollutants (Boldt et al. 2004; Lejon et al. 2008). Interestingly, the WCBMB technology is currently becoming the most exciting area of research for the detection of environmental pollutants, and it also provides the status of pollutant bioavailability, bioremediation and toxicity.

The biosensor is a device containing immobilised biological material in intimate contact with a compatible transducer, converting the produced biochemical signal into a quantifiable signal (Gronow 1984; Chien and Shih 2007) (Fig. 1). In the biosensor, the bioavailable fraction of the environmental pollutant is identified using a promoter and reporter gene construct. The readout depends on the gene expression, which is usually achieved by creating transcriptional fusions between a promoter and the reporter gene. The downstream expression of marker protein provides a measure of the availability of particular xenobiotics in the contaminated environment (Liu et al. 2004; Nouri et al. 2011). Biosensors supply an inexpensive and straightforward way of ascertaining contaminants; moreover, living organisms in the biosensor also provide information related to the toxicology of different substances and depict the mutagenic consequences of samples with high sensitivity (Fig. 1).

A great deal of concern has been devoted to introducing WCBMB in comparison to traditional methods (Hansen et al. 2001). In this review, we focus on the application of WCBMB as they are more sensitive, selective and specific for the detection of pharmacological pollutants; they provide information about the physiology and toxicology of a sample (Fig. 1). Here, we describe the recent advances in the field of whole-cell biosensors specific to heavy metals and xenobiotic compounds. More specifically, we explore several whole-cell biosensor examples established in biomedical and environmental sensing for the identification of bioavailable fractions of compounds in food specimens, drug screening and pharmacology-related samples (Gui et al. 2017; Mittal et al. 2020). Finally, we underline the future application of microbial biosensors in terms of biomedical and environmental safety concerns.

\section{Main Text}

\section{Whole-Cell-Based Microbial Biosensors (WCBMB)}

A great advantage in the field is the use of whole microorganisms, such as bacteria or fungi, for biosensors, along with the bioreceptor component (Vo-Dinh et al. 2000). These microbial biosensors are genetically designed by coupling with a reporter gene to produce a signal with a contaminant-sensing part that replies to chemical or physical changes, such as the influence of a particular analyte (Biran et al. 2003). When these biosensors are brought out to such a change, the detecting component induces the reporter gene through a biochemical pathway inside the cell. Subsequently, the reporter gene generates a measurable activity, such as releasing visible light, which reveals the magnitude of chemical or physical change (Biran et al. 2003; Tauriainen et al. 2000, 2003). Usually, the ability of the cell to sense is altered to integrate the transducer activity. Several parameters can be assayed, such as bioavailability, toxicity and genotoxicity. In this way, it becomes straightforward to estimate the amounts of xenobiotics present at the polluted site. When compared with the use of isolated and purified enzymes, the use of whole cells as biocatalysts presents various benefits, the most significant being the increased stability and security from intervening contents. Therefore, it becomes desirable to use whole-cell biosensors for the assessment of pollution levels.

\section{(i) Reporter Genes and Proteins for Whole-Cell-Based Microbial Biosensors (WCBMB)}

The expression of any gene for the development of whole-cell biosensors requires a vector or plasmid that acts as a vehicle for transferring a particular gene and further helping in its expression (Kaur et al., 2017). In this scenario, the desired gene must be connected to the reporter gene with a strong or weak promoter. A reporter gene specifically needs to be highly sensitive, have a non-invasive detection capability, and must not be present in the native organism itself (Daunert et al. 2000). During the process, the altered organism with the potential to produce sensing enzymes is induced in the presence of heavy metals or xenobiotics. The whole event activates the reporter gene that provides the amplified signal for the presence of a pollutant in the environment. Table 1 shows some of the biosensors with their 
specific host organisms and the relevant heavy metals and xenobiotics. The selectivity of a reporter assay largely depends on the type of target to be detected.

Green Fluorescent Protein (GFP) is a reporter gene derived from jellyfish (Chalfie et al. 1994). It has a specific auto-fluoresce and therefore does not require a substrate, cofactors or ATP and can remain stable for a long duration (Soboleski et al. 2005). Furthermore, the firefly luciferase (luc) reporter has been widely incorporated into WCBMB because of its broad linear range (7-8 orders of magnitude) and higher sensitivity (Welsh et al. 1997). Likewise, $\beta$-galactosidase (lacZ) is considered a highly efficient reporter with an excellent transfection efficiency monitoring capability (Jain et al. 1991). It offers other unique advantages such as rapid and straightforward sample usage via colorimetric and fluorescent methods. In addition to this, the availability of colorimetric or fluorescent substrates for lacZ provides the clear advantage of a decreased detection range. A regulatory protein must be able to interact with the target analyte or the contaminant to produce the quantifiable signal, making the entire cell-based biosensor a successful detection platform. Some of the transcription factors have also proved to be responsible for sensing certain pollutants. For example, Kim et al. (2016) developed heavy metal-detecting microbial biosensor by using a cadC regulator and a cadO operator found in Bacillus oceanisediminis 2691, as bacterial populations of ocean sediments contain heavy metal resistance operons. Another biosensor for $\mathrm{Cd}$ was fabricated using the GFP reporter gene under the control of cad promoter and cadC gene of Staphylococcus aureus plasmid pl258, with a better response time and a sophisticated detection limit (Kumar et al. 2017). In another report, a metal-responsive operon (cop-operon) was used to generate a cell-based biosensor against copper (Cu). Also, a genetically engineered $E$. coli was developed, with enhanced sensitivity and accurate bioavailable Cu quantification (Kang et al. 2018). Furthermore, a whole-cell biosensor harbouring fusion genes responsive to metal toxicants has been prepared based on pZntA and eGFP. The metal efflux system was disrupted to enhance the metal-binding property of ZntR, and the selectivity and sensitivity of the biosensor were increased by changing the amino acid sequence of ZntR (Kang et al. 2018).

\section{(ii) Advancement of Synthetic Biology-Centreed Genetic Circuits for Whole-Cell-Based Microbial Biosensors}

A plethora of research demonstrates viable alternatives to conventional and costly analytical methods; however, their realisation under field conditions is challenging. The experimental scenarios in the laboratory are confined to limited and controlled conditions, which are quite different from the field conditions. Accidental release or gene transfer from genetically modified organisms are possible. With the advent of advanced technologies, synthetic biology can be employed to overcome limitations associated with WCBMB made with recombinant DNA technology.

Synthetic biology uses engineering concepts to construct natural genetic circuits to process information that considers cellular components such as biomolecules including proteins and nucleic acids. This genetic element acts as molecular Lego units that can be assembled into functional synthetic circuits with broad applicability (Ali et al., 2017; Saltepe et al. 2017; Wagner et al. 2019). The smart cellular system can navigate complex molecular events during a response signal generated by any external stimuli. It is comprised of diverse transcription factors, promoters, operators, regulators and genes of interest, and the complex networking among various genetic elements can be used to design synthetic genetic circuits to perform novel functions ranging from environmental monitoring to the detection or killing of pathogens (Brophy and Voigt 2014). In this context, the analogy to logic gate signals is essential in setting up a finetuning between regulatory systems of the target organism.

One of the promising aspects of synthetic biology is the programming of cellular entities in such a manner that makes them more effective in the real-time monitoring and reporting of analytes. The prime importance of designing a synthetic circuit with the advent of biocomputing increases the number of signals produced in a controlled manner. The emerging field of biocomputing employs computing information to assemble molecular biology parts into the whole cell to purposefully link the genetic circuit to the physiological state of the cell (Goni and Nikel 2019).

\section{Overcoming limitations with genetic engineering}


We have previously discussed the various aspects of WCBMB, and despite their advantages, there are concerns regarding their biosafety, low sensitivity, low limit of detection and confined dynamic ranges (Dana et al. 2012; Shemer et al. 2017). Therefore, substantial research has been diverted in creating suitable interconnected networks with predicted and tuneable behaviour. The significant components of gene expression regulation include ligand-inducible promoter engineering (Chen et al. 2018), translational efficiency tuning (Wang et al. 2014) and control of protein degradation (Camerone and Collins 2014). These components have been widely described in improving the performance of genetically encoded biosensors (Chen et al. 2018; Merulla et al. 2015; Wang et al. 2015). The synthetic biologically driven WCMB hold a promising position in sensing several environmental contaminants with enhanced sensitivity and robustness. Another possible point is the attachment of the nanoparticles which will further improve the efficacy of biosensors in a biological system using the nano-bio interaction (Holzinger et al. 2014; Mittal et al. 2020; Yadav et al. 2021).

Recently, Jia et al. (2019) designed the arsenic (Ar) whole-cell-based biosensor, which significantly provides 10-20 times more robust responses in the presence of an analyte. The authors used a well-studied Ar resistance operon and prepared a whole-cell-based biosensor engineered by synthetic biological approaches. The positive feedback improves the sensitivity of the WCBMB and amplifies the signals to a significant level. The E. coli consists of an ars operon with a regulator (arsR), permease (arsB) and reductase (arsC). In the absence of Ar, arsR remains bound and inhibits the transcription from the promoter. They have been constructed purposefully through the mechanism of genetic circuit engineering with an enhanced positive feedback amplifier, using the LuxR auto-regulatory element to the Ar. The two plasmids were created to improve the signal and intensity of the output. One of the plasmids contains Pars and arsR with an mCherry reporter gene, providing the signal intensity with an increased concentration of Ar.

On the other hand, in the second plasmid, mCherry, was replaced with a variant of LuxR placed with a transcriptional activator that is controlled by an arsR-Pars circuit, whereas mCherry, together with LuxR, was placed under the control of Pluxl. These plasmids are coupled in the presence of Ar; LuxR in the first plasmid gets activated, which in turn activates the mCherry and LuxR from the second plasmid. Additionally, they both can activate their expression. As a result, a positive feedback amplifier was maintained that potentially enhances the output signal (Jia et al. 2019).

\section{Measure for using the WCBMB biosensors}

Physical biocontainment is a biosafety alternative for utilising cell confinement to bioreactors or encapsulation in alginate or silica beads (Chang and Prakash, 2001; Papi et al., 2005). However, physical containment alone is not sufficiently effective. Therefore, to avoid the uncertainties related to biosafety, risk governance comes into a picture that develops specific strategies to minimise the risks.

Several researchers use plasmids that carry only the gene of interest in genetically engineered biosensors instead of inserting the complete genome. Additionally, the designed vector does not share the homology with mobile elements and the host's genome, which creates another safety possibility (Bensasson et al., 2004). Although these strategies minimise the risks, plasmid transfer is also a chance through other organism's natural transformation mechanisms (Thomas et al., 2005).

In order to provide further safety assurance, we collected seven significant points from the literature for considering measures to be taken while working with genetically engineered biosensors. The detailed points are as follows,

1. A complete understanding of auxotrophy for WCBMB provides the necessary biosafety assurance. Therefore, auxotrophy could be used as an excellent method to reduce the escape risk since engineered bacteria can only be grown in complementing substance. It was found that the amino acid auxotrophy is predominantly utilised, but other auxotrophies, including genes for carbohydrate and lipid metabolism, could also be considered into account for the biosafety assurance of WCBMB (Baba et al., 2006). Nonetheless, auxotrophy is also associated with certain drawbacks such as toxic effects due to overexpression of complement (Vidal et al., 2008) or metabolic cross-feeding where plasmid-free cell relies on their neighbour prototroph for metabolic compounds. The problem was 
overcome using the modular multilayered biosafety platforms, including safeGuard or GeneGuard. Furthermore, a more complex fourlayered, robust system integrated with riboregulators, engineered modules, auxotrophies and supplemental repressors were prepared that demonstrated minimised escape frequency (Gallagher et al., 2015). In theory, auxotrophy can be extended with engineered hosts that rely on synthetic cofactor for synthetic metabolism. This could create a potential barrier to information transfer. An example is that utilising non-canonical amino acids as a synthetic cofactor for engineered E. coli renders six essential genes for ncAA L-4,4'biphenylalanine (BFA) (Lajoie et al., 2013).

2. Inducible systems could be another strategy of biocontainment achieved by the inducer of gene expression uncommon to the environment. Thus, engineered traits will be displayed under the conditioned and controlled environment.

3. Kill switches or induced lethality is an active containment strategy for biosafety purpose. The engineered microorganism becomes dependent upon the addition of an inducer signal in order to survive. Once the Kill switch gets activated, it leads to the cell membrane disruptive protein; Hok activation further activated cell death (Gerdes et al., 1990). The artificial cell division advancement brought us towards limiting engineered cells life span by automatic cell death. A synthetic gene network includes a riboregulated transcriptional cascade and a recombinase-based cascade of memory units that counts three molecular events (Friedland et al., 2009). These counting circuits can be linked to the intracellular cell cycle cues that limit their life span.

4. Additional regulatory elements could be employed to constrain the gene expression or microbial replication to prevent undesired consequences (Gallagher et al., 2015). The utilisation of the dependency devices provides a clear advantage, for instance, toxinantitoxin pair in which the activity of small toxin is nullified by cis-encoded antitoxin (Hayes et al., 2011). It is a combination of stable toxin and unstable antitoxin that can be placed at different parts, i.e. toxin on plasmid and antitoxin on the cell's genome (Hayes, 2003).

5. Another approach is based on the DNA barcoding system that makes the task simpler by tracking the engineered microorganism employed in the field. With advancements in DNA sequencing technologies, new synthetic DNA can be sequenced directly in environmental samples. The genetic barcodes can be employed in the synthetic operon or DNA 'watermarks' embedded in multiple genomic locations that could help identify modified microbes in the environment (Gibson et al., 2010). Likewise, we can also incorporate watermarks directly into the synthetic genes via codon usage optimisation (Liss et al., 2012).

6. Refactoring the existing genetic code involves designing novel genomes utilising non-canonical genetic codes (Lajoie et al., 2016, Mukai et al., 2017). It is also known as codon reassignment that takes three routes- sense to stop, stop-to-sense and sense-to-sense or triplet-to-quadruplet with modified aminoacyl tRNA synthetases (aaRS)/tRNA pairs creating alternative code (Bezerra et al., 2015). Such engineered organisms are sufficiently disruptive so that the translated protein is non-functional under the natural organism as it provides natural code to the system, thus preventing information transfer. Sense-to-stop or stop codon suppression can be exploited for codon reassignment through engineered aaRS and tRNA (or orthogonal pair) that can easily recognise non-canonical amino acid (ncAA) without interfering with cellular aaRS/tRNA pair (Chin, 2014, Des Soye 2015). Stop codon assignment within an essential gene provides additional benefit as the absence of charged suppressor tRNA prevents engineered information transfer. Sense-to-sense reassignment is not direct but employed via sense-stop-sense and removing multiple codons (Ostrov et al., 2016), but this strategy is not widely explored. The semantic containment or orthogonality in the genetic code offers double containment benefit, engineered information via altered genetic code and ncAA dependent auxotrophy. Furthermore, engineered microbes can no longer exchange their genetic parts with natural counterparts due to their unique biochemical language.

7. Xenobiology aims to design Xeno nucleic acid (XNA) that do not exist in nature, and the engineered microorganism that harbours it will not survive outside their destined environment. Also, the sugar moiety of the DNA backbone is changed by extensively modifying their functional groups, size and isomerisation states to form anhydrohexitol nucleic acid (HNA) (Hendrix et al., 1997), threose nucleic 
acid (TNA) (Schöning et al., 2000), locked nucleic acid (LNA) (Anosova et al., 2015), glycerol nucleic acid (GNA) (Zhang et al., 2005), cyclohexene nucleic acid (CeNA) (Wang et al., 2000). A xenobiotic host would require engineered RNA polymerases and other additional replication and transcription components compatible with XNA. A modification in the nucleobase is also resulting from the diversification of the nucleotide pairs.

\section{Critical parameters used in synthetic biology: biocomputation aspect}

Mechanical model predictions based on the previous assumptions are possible by using various algorithms that can further be applied to make a reliable genetic circuit. Boolean logic gates are helpful in designing predictable computational gene circuits, where genes and proteins can respond according to the changing environmental signals (Nielsen et al. 2016). In this regard, a conceptual mechanical model of arsR regulation was developed based on the Ar resistance element of $E$. coli. Here, the author tested two types of circuits, one with the feedback circuit hold arsR controlling its own as well as the EGFP reporter expression and another one with the uncoupled circuit in which ArsR is controlling the expression of EGFP from the promoter of ars. The efficiency of the predicted model design was confirmed experimentally, and the model may further be useful for preparing detailed modelling of not only regarding the Ar sensor, but also other types of bioreporters (Berset et al. 2017).

Jia et al. (2018) introduced six gene circuits for the whole-cell-based biosensor for $\mathrm{Pb}$ by rearranging various regulatory elements in the $\mathrm{Pb}$ resistance operon and additionally incorporating positive feedback loops. The operon resistant for $\mathrm{Pb}$ encodes six genes and consists of regulatory pbrRT on one side and pbrABCD on the other side. The native operon was reconfigured by rearranging the position of pbrRT and GFP on the same hand under the control of different promoters with positive a feedback loop design, which resulted in an enhanced output signal; this demonstrates the advantage of introducing synthetic biology for purposely reconfiguring the genetic elements for increased sensitivity and specificity of the biosensor (Jia et al. 2018).

Synthetic biological circuits are a genetic engineering framework where biological components are configured to execute logical functions within a cell that resemble electronic circuits. One of the critical categories is the Logic AND gate circuits. The logical AND gate is the signalling channel, where if Signal A AND Signal B are connected, only the anticipated gene product will produce.

The environmental signals depend on the presence or absence of small molecules (lac, trp operons) (Setty et al., 2003). A complex array of multiple signals integrated by the bacteria enhances the sensing sensitivity and specificity. The bacterial system integrates environmental signals utilising various mechanisms, including a two-component system, transcription factors and small RNA (Hoch and Silhavy, 1995). The introduction of synthetic biology allows the designing of synthetic cellular circuits often intended to implement required functions. For instance, genetic logic gates can be utilised to control the response against stimulus input signals. Various logic gates can be built using transcription factor genes, regulatory elements or protein-protein interactions. The development of these circuits depends upon the particular set of inputs and outputs that can be made modular if connected to different inputs to drive different outputs. Various environmental pollutant-like arsenic (Joshi et al., 2009), xylene (Paitan et al., 2004) and Pseudomonas aeruginosa-responsive (Saeidi et al., 2011) sensors can be wired to a multiple-input AND gate, allowing cells to report and neutralise a toxic combinatorial circumstance. It is often possible for transcriptional logic gates to combine promoter or operator sequences to control transcription of the output (Gander et al., 2016, Stanton et al., 2013). In this genetic AND gates, each AND gate integrates two promoter inputs and controls one promoter output. This allows the gates to be layered by having the upstream circuit's output promoter serve as the input promoter for a downstream circuit. The output of the circuit is ON only when all the inputs are ON and the output will be OFF if any of the input is OFF. In one of the AND gate circuit, the orthogonal system from P. syringae was utilised to construct E. coli with co-activating genes hrpR/hrpS (regulated by separate promoters) regulating $\sigma 54$-dependent transcription. The final output response was generated only when two individual environmental responsive transcriptional inputs expressed (Wang et al., 2011). The AND gate can also be prepared using similar inputs and outputs as promoters. Additionally, a set of promoters having the capability to sense different environmental signals can be concatenated to and resulting AND gates activate only in the presence of all the conditions (Anderson et al., 2007).

Genetic circuits, such as AND gates that include multiple sensory inputs, can also be used to develop the sensitivity and selectivity of the sensor. In this approach, regulated promoters are integrated with NOT gate output to produce a combined NAND gate, thus allowing

Page 7/32 
accurate measurement of biological control (Wang et al. 2011). In this context, Park and Taffet (2019) developed a uranium (U)-responsive whole-cell-based bioreporter in Caulobacter crescentus by integrating a two-component signalling system along with UzsRS and UrpRS and the signal amplifier protein UzcY within the AND gate circuit (Park and Taffet 2019). In another study, the multiple heavy metal ionsensing heterologous transcriptional modules of $E$. coli were made in AND gate fashion that was able to produce fluorescent signals. The authors prepared an AND logic gate that was based on the previously known hrp (hypersensitive response and pathogenicity) operon from P. syringae. First, the two-input AND gate was prepared, in which HrpR and HrpS, under the control of the Ar-responsive promoter, produced from the $\mathrm{As}^{2+}$ promoter, is noninverted. The HrpV, under the supervision of the $\mathrm{Hg}$-responsive promoter, is produced from inverted $\mathrm{Hg}^{2+}$ input. The output will be turned ON only in the presence of Ar. In the next strategy, the two-input AND gate was extended to a three-input gate in which HrpS was controlled by the Ar-responsive promoter and HrpR by the QS-responsive promoter (Wang et al. 2014).

Another critical part of the genetic circuits is a toggle switch that can also be introduced into the biosensor to reduce the background noise created by the fluorescent signals. Wu and co-workers (2009) constructed a toggle switch for a whole-cell Cd sensor. The toggle circuit was designed with the $\mathrm{Cd}$ (III)-sensitive regulatory promoter PcadR of Pseudomonas putida 06909 fused with gfp and laclq genes. The Ptac, which is an IPTG-inducible promoter, was placed upstream of the cadR gene encoding CadR protein that, in the presence of IPTG, represses the PcadR promoter. The presence of $\mathrm{Cd}$ ions leads to the expression of Lacl and GFP proteins. The Lacl represses the Ptac promoter, which consequently leads to the decreased expression of the cadR gene and the increased expression of the GFP gene. The detection limit of the toggle switch was 20 times less than that of the non-toggle circuit with lower background fluorescence (Wu et al. 2009).

\section{Enhanced sensitivity: multilayering approach}

The growing field of synthetic biology offers new avenues for the precise construction of novel engineered biosensors, but the problem of sensitivity persists, depending on several factors. Most of the reports only focused on a single aspect of the engineered biosensor, leading to a trade-off between different performance parameters; for example, decreased LOD may increase the background expression, leading to high background noise. Therefore, it is crucial to keep all parameters in mind to enhance sensor performance in a real scenario. An ultrasensitive E. coli-based sensor was devised by employing the signal amplification methodology (Wang et al. 2015).

A multilayer sensing module was created by Wan et al. (2019), integrating three significant parts: the sensing module, the computing module and the output module. The signal output was enhanced by tuning different parts of the module, such as maintained densities of receptor and ligand in the sensor module, the activator-based amplifier in the computing module and the multiple amplifier cascade in tandem. The authors used a well-known Ar sensor (J101-arsR-ParsR-gfp) that was modified purposefully. The constitutive promoter of the Ar sensor was replaced with two weak promoters to maintain the receptor (arsR) concentration encoded through that promoter. As a result, sensitivity and output amplitude were significantly increased.

Additionally, the output expression was further improved up to 440-fold (without a signal noise) and a limit of detection of up to 100-fold only by incorporating two layers of a transcriptional amplifier cascade (Amp30E-Amp31E11A) in between the sensor and the reporter module. However, to decrease the metabolic load on the host system, this amplifier cascade was connected with a tight input sensor (J117-arsR-ParsR) in a low-copy-number plasmid. The incorporation of the third amplifier (Amp33RinA) in a cascade consequently exhibited an inadequate dose response. Therefore, there was a shift to a high-copy-number plasmid along with its promoter and reporter, and as a result, the three-layered amplifiers were able to enhance the sensitivity and output amplitude irrespective of the type of the used amplifier. The engineered sensor exhibited a high output range for other contaminants, e.g., Hg. The sensor's background leakage was also be minimised by using protein-based post-translational degradation control (Wan et al. 2019).

\section{Recent advances for biosensors specific to heavy metals}

\section{Arsenic}


Accelerated industrialisation leads to uncontrolled anthropogenic activities, contributing to the accumulation of heavy metals in the environment. For the detection of heavy metals, various biosensors have been developed (Table 1). According to the WHO, arsenic, which can be present in groundwater, is hazardous in its inorganic form as its long-term use can cause tumours and cardiovascular diseases (www.who.int). It is also a well-known harmful metalloid that occurs in natural environments mainly as a result of geologic processes (e.g., volcanic activity) and from artificial sources (e.g., heavy industry, pesticides). Small-scale analytical protocols require costly instrumentation and highly skilled personnel, thereby limiting their applicability and on-site detection ability; these assay protocols also have low detection limits, which further restrains their application (Komorowicz et al. 2016). Therefore, novel and more sensitive sensors for the detection of heavy metals have been created by designing reporter gene systems along with Pseudomonas fluorescens as host cells. The host range of two arsenites (PTPT21 and pTPT31) sensor plasmids that show metal availability through luminescence character was created and assigned into Escherichia coli DH5a and Pseudomonas fluorescence OS8. These biosensors are useful for online observations of contaminants, which is not possible via conventional methods (Petänen et al. 2001).

In another report, the generation of WCBMB using two different forms of arsenic $\left(\mathrm{As}^{3+}\right.$ and $\left.\mathrm{As}^{5+}\right)$ contaminants by joining an arsenicresistant promoter and the regulatory gene arsR to Escherichia coli DH5a, and phiYFP and inserted into $E$. coli DH5a to create an arsenicresistant biosensor (WCB-11), has been described. The experimental results suggested that the biosensor has an excellent activity to arsenic and the expression of phiYFP. When strain WCB-11 was exposed, yellow fluorescence occurred in the presence of $\mathrm{As}^{3+}$ and $\mathrm{As}^{5+}$, which was time- and dose-dependent. The newly synthesised construct is an inexpensive and accessible method for the detection of arsenic in contaminated sites (Qing Hu et al. 2010).

Alternatively, a GFP-merged ArsR protein, attached to a cis-element, was used, which loses the binding capability to arsenic at the Asbinding conformational states. The GFP-tagged ArsR and cis-element complex immobilised on a solid surface in the presence of samples containing toxic metals. The quantification of metal ions is directly proportional to the fluorescence intensity; where the light intensity significantly increases with an increase in the concentrations of toxic metals. The detection limit was $5 \mu \mathrm{g} / \mathrm{L}$ for As(III) in purified water, tap water and bottled mineral water. This biosensor was stable at $4^{\circ} \mathrm{C}$ and responded to $5 \mu \mathrm{g} / \mathrm{L} \mathrm{As}$ (III). Genetically produced biosensors are sensitive, less time-consuming, portable, and could offer benefits such as on-site detection of toxic metals in drinking water (Jia et al. 2019). In a pioneering study, the signal-to-noise ratio was enhanced and the detection limit was significantly decreased by creating plasmids bearing three tandem copies of an ars promotor/operator and a gfp gene placed in trans in another plasmid bearing a lac promoter/operator or a T7 promoter, which is under the control of IPTG. The following construct was incorporated into recombinant $E$. coli cells that were effectively able to sense as at the lowest detection limit of $7.5 \mu \mathrm{g} / \mathrm{mL}$ reported to date (Tani et al. 2009).

The use of whole cells as biosensors is more convenient as they are self-sustained and can detect multiple analytes simultaneously, with a straightforward and quantifiable output. The bacterial operon, which can either populate on the plasmid or on the chromosome, is responsive against arsenic (Fekih et al. 2018) and can further be exploited for generating sophisticated sensors. Various bacteria, such as Bacillus subtilis, can survive in tropical environments and can therefore be used at high temperatures for the detection for arsenate in water samples.

The baculosensor was fabricated that composed of ars promoter, repressor arsR of $B$. subtilis fused with a xylE reporter on a pVK168 plasmid with an enhanced detection limit as suggested by the WHO. This biosensor is more sophisticated for arsenic recognition, as the output was reported simply by analysing the yellow-coloured dye within $4 \mathrm{~h}$ of exposure with arsenic (Wicke et al. 2018). Most of the bacteria with an operon on a plasmid show resistance against arsenate by establishing a robust efflux system. In one study, E. coli-based WCBMB used an ars operon fused with mutant GFP (due to the high stability and quantum yield) as a reporter gene and incorporated into non-pathogenic E. coli MG1655. This constructed biosensor was able to detect bioavailable arsenic ions as well as arsenate content in water within $2 \mathrm{~h}$ of induction, unlike other analytical methods that measure total arsenic content (Elcin et al. 2018).

Most whole-cell-based biosensors rely on the inducible operon that, whenever it senses a particular metal, activates transcription. A genuine arsenic bioreporter was created using the nikA promoter of the repressible nik operon from E. coli, which represses in the presence of sufficient nickel fused with egfp as a reporter domain to generate pNik-eGFP plasmid (Yoon et al. 2016).

Page $9 / 32$ 


\section{Cadmium}

Widespread development, economic growth and water scarcity contribute to the increased accumulation of Cadmium (Cd) and, thus, disrupt the ecological balance. The massive accumulation of $\mathrm{Cd}$ in the environment is hazardous for organisms, especially in the case of chronic exposure. Inhalation and ingestion of any remarkable amount of $\mathrm{Cd}$ lead to respiratory tract infections and may also cause liver and kidney poisoning (Mahmood et al. 2019). Although the accumulation of $\mathrm{Cd}$ in the environment can cause toxicity, it is still widely used in industries due to its broad applications. Cadmium is released as a by-product from various sectors, mixes with waterbodies and reaches the food chain (Hayat et al. 2019). In this context, it is crucial to develop a method that can monitor and detect the presence of hazardous $\mathrm{Cd}$ in the environment with high sensitivity efficiency in a cost-effective manner.

To create a reporter gene construct with high expression of GFP under the control of the cadR gene that confers resistance for Cd, the recombinant strain E. coli cadR30, carrying the cadR gene from Pseudomonas aeruginosa BC15 in pET30b expression vector, was used and cloned. Clones were detected by increased expression of green fluorescence protein under UV illumination and separated on SDSPAGE. Thus, a GFP-based E. coli bacterial biosensor for the detection of heavy metals in soil and water was constructed (Edward and Selvam 2011).

The profiling of gene expression associated with Cd treatment identified novel responsive genes in the methylotrophic yeast Hansenula polymorpha. A set of genes showed more than a 6 -fold increase in their expression on treatment with $300 \mu \mathrm{M} \mathrm{Cd}$ for $2 \mathrm{~h}$. Promoters with approximately 1,000 bp upstream were merged with yeast-enhanced GFP gene. Promoter strength and specificity were assessed by inserting the reporter gene construct into H. polymorpha; the H. polymorpha SEO1 gene (HpSEO1)-derived promoter most strongly expressed the GFP gene on treatment with $\mathrm{Cd}$. Thus, the HpSEO1 promoter can potentially be used as a bio-element in constructing a whole-cell biosensor to mitigate heavy metal contamination, especially for Cd (Jeong et al. 2007).

A GFP-based metal-binding biosensor with cis-element-bound GFP-tagged CadC proteins was produced for the on-site determination of toxic metal ions. This biosensor, along different water samples containing metal pollutants, was incubated and immobilised on a solid surface. Fluorescence intensity was measured for metal quantification and increased with increasing metal levels. In purified water and tap water, as well as bottled mineral water, detection limits of 1 and $10 \mu \mathrm{g} / \mathrm{L}$ for $\mathrm{Cd}(\mathrm{II})$, respectively, were achieved by the use of a fluorometer after 15 mins. The biosensor was stable at $40^{\circ} \mathrm{C}$ and responded to $\mathrm{Cd}$ (II). The solid phase-based biosensor for Cd is highly sensitive, portable, less time-consuming and can be used for online monitoring of xenobiotics in drinking water (Siddiki et al. 2011).

Most of the previously developed biosensors rely on the presence of metal resistance operons with active promoters and regulators, which are controlled by transcriptional regulators that can bind with the different promoters even in the absence of Cd. Moreover, most of the promising biosensors use the single output mechanism, where the signal output is fluorescence or luminescence. Multiplex microbial biosensors have unprecedented capabilities to monitor the health and metabolic activity of the cell as well as the environmental fluctuations that cause variability in the signal output pattern. Bereza and co-authors (2017) constructed a multiplex Cd biosensor by assembling a single-output $\mathrm{Cd}$ biosensor built along with its promoter/operator and constitutively expressing mrfp1. This construct was transferred into three different Gram-negative bacterial species (Pseudomonas aeruginosa, Shewanella oneidensis, Enterobacter spp.) isolated from Cd-contaminated soil, resulting in the production of a dual output green and red signal that facilitates the simultaneous measurement of bacterial growth and viability (Bereza et al. 2017).

\section{Chromium}

Chromium is the most common element found in the earth's crust and is widely used in industrial applications such as leather tanning, textile dyeing, ink pigmentation and pharmaceutical drug production, resulting in its heavy discharge into waterbodies (Bharagava and Mishra 2018). Such uncontrolled release puts pressure on aquatic systems and, consequently, affects marine life (Handa and Jindal 
2019). Because of the accumulation of chromium in the food chain, human health is at risk. Unlike other contaminants, heavy metal persist longer in the environment and are toxic even at lower concentrations (Li et al. 2019).

Salmonella typhimurium TA1535 was genetically modified with plasmid pPLS-1, containing the promoterless lux operon of Photobacterium leiognathi as reporter element under the guidance of a DNA damage-dependent SOS promoter from ColD as sensing element, known as SOS-LUX-TEST. This system depends on the level of xenobiotics, stimulating DNA damage in the microbial cell and emitting light that can easily be quantified.

Similarly, the LAC-FLUORO-TEST, used for the identification of physiological responses of cells to different cytotoxic materials, applies the bacterial protein expression vector pGFPuv, integrated with GFP. The presence of xenobiotics results in a dose-dependent decrease in GFP fluorescence. Comparative studies have been performed in the presence of heavy metals through $\mathrm{K}_{2} \mathrm{Cr}_{2} \mathrm{O}_{7}$ and $\mathrm{CrCl}_{3}$ simultaneously. Luminescence induction and fluorescence reduction respectively have been measured to show the genotoxic and cytotoxic ability of $\mathrm{Cr}$ metal ions. Such tests are easy to conduct, inexpensive and environmentally friendly (Elke et al. 2002).

One of the studies described the construction of a $E$. coli bioreporter system by creating a transcriptional fusion between the GFP reporter gene, the genetic unit of the promoter (chr) and the chromate regulator (chrB) obtained from Ochrobactrum tritici 5 bv11. The construct was then cloned into the broad host range vector pPROBE - NT, incorporated into E. coli DH5a and designated as pCHRGFP1. Another construct, pCHRGFP2, was designed by inserting the mob gene of pCHRGFP1, which was introduced in the 0 . tritici strain. In this manner, two bioreporter systems were created to assess $\mathrm{Cr}(\mathrm{VI})$ and $\mathrm{Cr}(\mathrm{III})$ levels (Branco et al. 2013). The bioluminescent whole-cell-based bioreporter was developed using E. coli recA:luxCDABE, providing a more precise evaluation of bioavailable Cr. It was also tested in a realtime scenario where the biosensor was applied to Cr-contaminated soil and seawater collected from oil spills (Jiang et al. 2017).

Bacterial whole-cell bioreporters have attracted considerable attention because of their powerful detection properties and their ability to detect bioavailable levels of contaminants in the sample. Nevertheless, most of the respective studies were performed in aqueous samples with the use of $E$. coli instead some other host organisms. Therefore, Jiang et al. (2015) used the native soil microorganism Acinetobacter baylyi ADP1 as a bioreporter. This biosensor consists of the promoter less luxCDABE cassette from Photorhabdus luminescens in its chromosome that is controlled by the SOS-inducible recA promoter. Acinetobacter baylyi ADPWH_recA with fused recA regulon, when exposed to different concentrations of $\mathrm{Cr}(\mathrm{VI})$ in soil samples, produced easily quantifiable bioluminescence (Jiang et al. 2015).

\section{Copper}

The ubiquitous metal ions such as $\mathrm{Cu}, \mathrm{Zn}$ and $\mathrm{Mg}$ play an essential role as cofactors for various enzymes that take part in metabolic processes. These ions can maintain cell integrity by regulating osmotic pressure. They are also crucial trace elements but can act as a toxin if present in higher concentrations (Maret and Wedd 2014; Rasheed et al. 2018). The microorganisms that inhabit the extreme environment loaded with high levels of heavy metals can sense even small fluctuations of metal concentrations. Many microbial-based biosensors have been developed for Cu identification but failed to detect the bioavailability of an analyte (Chandrasekhar et al. 2012). When studying the copper-responsive promoter in Achromobactersp. A022, the two regulator genes copR and copA (multicopper oxidase gene), along with a palindromic cop box sequence, were determined. The identified new strain was engineered using a lacZ reporter construct, pCOPRP, in E. coli; after modifying the host, expression was enhanced significantly (250-400 fold) for copper, but minimally to other metals. Thus, Achromobactersp. A022 is highly efficient in the detection of copper bioavailability; for E. coli, experiments are still laboratory-based (Ping et al. 2012).

In another approach, engineered Saccharomyces cerevisiae strains containing plasmids with the $\mathrm{Cu}^{2+}$ inducible promoter of the CUP1-gene from S. cerevisiae were combined with the lacZ-gene from E. coli. In this construct, the promoter was first stimulated by Cu ${ }^{2+}$, followed by the use of lactose, which acts as a substrate for quantification. The carbon source, lactose, is used if $\mathrm{Cu}^{2+}$ is present and leads to

Page $11 / 32$ 


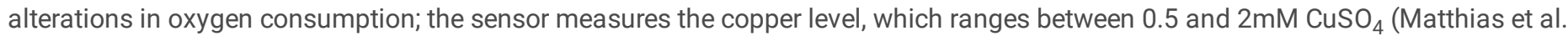
2000). One hypothesis describes that few microorganisms employ a mechanism to resist metal toxicity, maintaining metal homeostasis. Kang et al. (2018) exploited the gene operon present in E. coli and responsible for metal transport to prepare a biosensor against Cu. Upon $\mathrm{Cu}$ binding, the cop operon is regulated by the interaction between the promoter and its regulator in the presence of reporters, but the copA promoter was not as active as other promoters; this limitation was overcome by deleting copA and cueR from E. coli, further incorporated with a plasmid-harbouring pCopAp and GFP reporter.

The dual detection of $\mathrm{Cu}$, as well as gold (Au), was performed with engineered E. coli and Synechococcus sp. 7002-based biosensors by incorporating the transcriptional activators GolSA113T and GolSCL with a replaced metal-binding loop from CueR (part of a copper operon). This bacterial sensor produces fluorescence signals when it comes in contact with both Au and Cu. The GolSCL-based E. coli biosensor responded to even low concentrations of Au and $\mathrm{Cu}$. Finally, the Au and Cu sensors were expressed in the cyanobacterium Synechococcus sp. 7002, producing signals in response to Au only (Lacey et al. 2019).

In another study, Chen and co-workers (2017) designed a robust whole-cell biosensor for monitoring the bioavailable levels of Cu ions in tap as well as freshwater samples. The authors used several vital parts such as microbial chassis, promoters and output signal to develop a novel biosensor for $\mathrm{Cu}$. They successfully minimised the response time by examining betaxanthin, a plant pigment for fluorescence signals (Chen et al. 2017).

\section{Lead/Zinc}

Lead $(\mathrm{Pb})$ is a naturally occurring heavy metal in the earth's crust. Numerous industries are heavily relying on Pb because of its density, malleability, resistance against corrosion and low degradability. The significant use of $\mathrm{Pb}$ and its incorrect disposal results in uncontrolled environmental contamination. According to WHO guidelines, the allowed limit of $\mathrm{Pb}$ in drinking water is about $10 \mu \mathrm{g} / \mathrm{L}(\mathrm{WHO}, \mathrm{Geneva}$, 2011).

The fusion of a reporter gene to a sensitive metal ion gene, such as zinc and lead, produces biosensors. After many efforts, the limit of detection of a Pseudomonas putida KT2440-based Zn/Cd/Pb-biosensor could be increased by a factor of up to 45 by interrupting four primary efflux transporters for $\mathrm{Zn} / \mathrm{Cd} / \mathrm{Pb}$, causing the metals to concentrate inside the cell. Changes in sensor elements lead to a higher specificity of bioreporter genes. From P. putida, a Zn-specific bioreporter was achieved by using the promoter of the cadA1 gene as a sensor element. The engineered $P$. putida reporter strain can detect $\mathrm{Zn}^{2+}$ concentrations about 50 times lower when compared to other available $\mathrm{Zn}$ bioreporters. The achieved limit is much lower than the permitted limit values for $\mathrm{Zn}$ and Pd in different soil and water samples, allowing the identification of minute xenobiotic concentrations in the environment (Anu et al. 2010).

The luxCDABE genes of Vibrio fischeri and the metal-responsive smt operator/promoter region of Synechococcus PCC7942 were fused in plasmid DNA (pJLE23); this plasmid showed metal ion-inducible luminescence to transformed cyanobacteria. Synechococcus PCC7942 (pJLE23) was adequate in $\mathrm{ZnCl}_{2}$ within a range of $0.5-4 / \sim \mathrm{M}$, as constituted by the stimulus of luminescence (Erbe et al. 1996).

Bereza and co-workers (2016) assessed the ecotoxicological level of Pb in environmental samples with the help of a biosensor which was created by using the host inhabiting the heavy metal-contaminated soil. The plasmic-based whole-cell bioreporter was constructed by fusing pbrR, a regulatory protein, and a reporter gene (GFP) that produces fluorescence in the presence of Pb. This construct was further incorporated into a low-copy-number broad host range plasmid and, subsequently, Gram-negative bacteria, including Pseudomonas, Shewanella and Enterobacter species (Bereza et al. 2016). 


\section{Mercury}

The bioaccumulation of heavy metals results in altered food chains, causing ecological imbalance (Wepener et al. 2001). The identification, quantification and monitoring of heavy metals typically involve expensive equipment and frequently require crucial sample pre-treatments. Recombinant bacterial biosensors have been produced, containing zinc regulatory gene zntR and zntA promoters from the $z$ t operon of $E$. coli to induce the expression of GFP reporter protein. The sensor can report up to 3-800 ppm of $\mathrm{Zn}^{2+}, 0.005-4 \mathrm{ppm}$ of $\mathrm{Cd}^{2+}$ and $0.001-0.12 \mathrm{ppm}$ of $\mathrm{Hg}^{2+}$ ions. Studies with the liquid medium have shown that the maximum stimulation for $\mathrm{Zn}^{2+}, \mathrm{Cd}^{2+}$ and $\mathrm{Hg}^{2+}$ was at 20, 0.005 and $0.002 \mathrm{ppm}$, respectively. The application of the pPROBE-zntR-zntA biosensor can therefore be the primary screening technique for aquatic heavy metal pollution (Gireesh and Chaudhari 2012).

The generated sensor is used for peculiar detection and studies on the bioavailability of metals by modified Pseudomonas fluorescens with reporter gene systems. One broad host is mercury (pTPT11) plasmids that emphasise metal occurrence by luminescence were established and inserted into E. coli DH5a and Pseudomonas fluorescence OS8. The capability of the strain OS8 to measure specific heavy metals in spiked soil and soil extracts is higher than that of conventional chemical analysis. The strain Pseudomonas was isolated from pine rhizosphere in oil and heavy metal-contaminated soil. It is a common soil bacteria and, therefore, an excellent agent for quantifying soil heavy metal bioavailability (Petänen et al. 2001). This environmentally relevant bacterial species offer a definite advantage in detecting environmental contaminants as they can mobilise the bioavailable portion of compounds to be used by other organisms coexisting with them in the ecosystem. Therefore, they can play an important role as biosensors. For instance, Rijavec et al. (2017) considered two bacteria, Pseudomonas putida and Allivibrio fischeri, in biosensor preparation. The Hg-sensing construct consists of the mer-lux element incorporated into $A$. fischeri as well as P. putida. The constructed biosensor has a lower limit of detection (100 times increased sensitivity) and can detect even the lowest concentration of $\mathrm{Hg}$ in the environmental samples (Rijavec et al. 2017). The potential colorimetric biosensor was prepared by Wang et al. by modifying the biosynthesis of soluble pigment pyocyanin under the regulation of $\mathrm{MeR}$, the signal-sensing transcriptional activator of $\mathrm{Hg}^{2+}$ that provides the visual detection signals. The construct exhibited extraordinary sensitivity for $\mathrm{Hg}^{2+}$, with high selectivity and sensitivity, showing a working potential within a wide $\mathrm{pH}$ range (pH 4-10) (Wang et al. 2020).

\section{Recent advances of biosensors for xenobiotic compounds: hydrocarbons and Pesticides}

A xenobiotic is a man-made chemical substance toxic to the ecosystem. To detect the accumulation of these compounds, several strategies are currently being used. One is the use of a luciferase-based whole-cell biosensor, which was constructed and characterised for measuring toluene, benzene, xylene and similar molecules. The reporter TOL plasmid from Pseudomonas putida mt2 was constructed by incorporating xylR, a transcriptional activator that binds explicitly to toluene-like compounds, and a luc gene under the control of promoter $\mathrm{Pu}$. The luminescence response of transformed $E$. coli proved to be a capable biosensor for measuring environmental contaminants. Furthermore, other than the biotechnological workhorse $E$. coli, different soil-borne bacteria, such as $S$. aureus, $P$. fluorescens and $P$. putida, have been used in the engineering of whole-cell biosensors (Renella and Giagnoni 2016), providing the additional advantage of monitoring soil-based contaminants.

The immediate use of industrial and agricultural chemicals results in elevated levels of toxic compounds in the environment (Bilal et al. 2019; Hernandez et al. 2018). These contaminants are potential carcinogens, endocrine disruptors and mutagenic in nature (Barrios et al. 2018; Bilal et al. 2017). The amelioration of these pollutants will have a profound impact on contributing significant efforts towards the success of mitigation and pollution management programs. The traditional strategies to monitor pollutants involve long detection periods and labour-intensive and costly equipment. In this direction, the whole-cell-based biosensor seems to be pivotal for the active sensing of environmental contaminants because of its improved sensitivity, selectivity and lower detection limits (Maduraiveeran and Jin 2017). Until now, various biosensors have been introduced to monitor an array of analytes including xylene, toluene, heavy metals, polychlorinated biphenyls (PCB), polycyclic aromatic hydrocarbons (PAH), alkyl sulphonates, among others (Chang et al. 2017).

\section{Hydrocarbons}


The lipophilic, inert and toxic properties of aromatic hydrocarbons classify them as severe environmental pollutants. Although chlorinated aromatics are under control in many countries, the major problem of their distribution in the environment still prevails. The potential development of recombinant microorganisms capable of bioremediation has increased with the growing knowledge of xenobiotics metabolism. Genetically modified microorganisms with a high degrading capacity for a wide range of chemical contaminants and bioremediation of soil, water and activated sludge can potentially be used as bioreporters.

Pseudomonas fluorescens HK44 was the first genetically modified whole-cell bioreporter containing the bioluminescent gene luxCDABE; the phenotype is linked to naphthalene catabolic pathways (Trögl et al. 2012). Soil contamination due to oil spills and petroleum-based products is the leading cause of environmental pollution and a great matter of concern (Cocârţă et al. 2017). The naphthalene types of PAH occur in the subsurface environment; they have high solubility and can cause cancer in humans. Sun et al. (2017) prepared a bioreporter which consists of a vector pWH1274_Nah incorporated with the naphthalene-degrading gene nahAD, cloned into a potent host Acinetobacter ADPWH_lux. The salicylate-inducible gene was introduced into the vector along with the luxCDABE operon; the constructed reporter was highly sensitive towards naphthalene (Sun et al. 2017).

Three reporter gene fusions were constructed through the use of a pcbC promoter of Pseudomonas sp. DJ-12 to identify and remediate xenobiotics such as biphenyl and 4-chlorobiphenyl through meta-cleavage dioxygenase. The genes used for production were luc, luxCDABE and GFPuv, inserted into E. coli XL1-Blue as a transformant host which emits light upon exposure to aromatic xenobiotics, e.g. 4-chlorobiphenyl, 4-hydroxybiphenyl, 2,3- dihydroxybiphenyl, catechol and 4-chlorocatechol. The cells containing the engineered gene fusions showed a concentration of $0.1 \mathrm{mM}$ for $10 \mathrm{~min}$ (Sang et al. 2004).

In another approach the construct was performed by fusing the dnaK promoter of Pseudomonas sp. DJ-12 or E. coli to the luc marker gene. The fusion product of dnaKp-DJ::IuxCDABE in Pseudomonas sp. DJ-12 dnaK showed a nearly 5-fold higher response to ethanol compared to dnaKp-EC::IuxCDABE in E. coli. Along with luc, the response was considerably weaker than that of lux. A biosensor containing dnaKp-DJ::IuxCDABE fusion was tested for bioluminescence production upon exposure to other aromatic xenobiotics, such as 4hydroxybenzoate, 4-chlorobiphenyl and catechol. Specifically, light emitted by dnaKp-DJ::IuxCDABE gene fusion showed sensitivity to $1 \mathrm{mM}$ biphenyl and 4-chlorobiphenyl when subjected to identification for $80 \mathrm{~min}$; there are similar results for other aromatic substances. This suggests that biosensors produced via dnaKp-DJ::IuxCDABE gene fusion have a high capacity to detect many aromatic compounds and different kinds of xenobiotics (Park et al. 2002).

The significant problems with the detection of hydrocarbons through bioreporters are based on their low solubility in water, leading to an enhanced response time and a weaker signal-to-noise ratio. To overcome this issue, the whole cell acts as a host, as it is better adapted to the metabolism of hydrocarbons. Sevilla et al. (2015) compared biosensors based on two different host systems: E. coli, which is not optimised for alkane degradation, and Alcanivorax borkumensis, which is a marine hydocarbonoclastic bacterium. These marine bacteria are better adapted to oil and can use hydrocarbons as a sole energy and carbon source (Naether et al. 2013). The construct was made by fusing the transcriptional activator AlkS from Pseudomonas putida OCT plasmid under the control of promoter PalkB with GFP as a reporter gene; AlkS activates the transcription in the presence of alkanes. This construct was cloned into the broad-host-range plasmid pSEVA431, resulting in pKSB1. The hydrocabonoclastic Alcanivorax borkumensis is more sensitive towards low-hydrocarbon-chain compounds such as alkanes, with significantly lower noise during fluorescence and four-fold lower threshold levels in comparison to $E$. coli, which was compromised by its higher sensitivity towards salt (Sevilla et al. 2015).

\section{Pesticides}

The extensive use of pesticides in modern agricultural practices leads to various pollution issues and, ultimately, ecological imbalance. Organophosphate pesticides or organothiophosphate (OP) compounds share a global insecticide market and are potent neurotoxins; however, they are widely used as pesticides. These compounds disrupt the action of acetylcholinesterase, which is required for the proper functioning of nerve cells. Therefore, it becomes imperative to assess the detrimental effects of this pollutant. In this sense, biosensors 
provide the definite advantage of sustainable production and stability as compared to other traditional assays. One of the broad-spectrum widely used organophosphate insecticide is chlorpyrifos (CPF). Its low water solubility, high soil absorption capacity and high mobility result in increased accumulation in the soil during application, causing various health hazards (Lester et al. 2017). By taking advantage of the distinctive properties of microbes, they can easily be be manipulated to enhance their use in practical applications. A cheaper alternative to the traditional approach is the monitoring of $\mathrm{CPF}$, which is dependent on the genetic-based whole-cell biosensor. On specific exposure to the pesticide, the target promoter gets activated and fuses with the suitable reporter gene, which in turn produces a higher exposure of the reporter gene and, ultimately, quantifiable signals. Whangsuk and co-workers (2016) prepared a CPF-sensing biosensor based on the CPF-responsive transcription factor (chpR) and the chpA promoter, which gets activated in the presence of CPF and produces fluorescence during positive response due to the presence of lacZ. Another plasmid consists of the atsBA gene that encodes the formylglycine-generating enzyme ( $F G E)$ and sulfatase; here, sulfatase was used as the reporter system. Both fusion plasmids were incorporated into the $E$. coli host system, and upon exposure to $\mathrm{CPF}$, chpR triggers the expression of the sulfatase gene that converts 4methylumbelliferyl sulphate to the fluorescent product 4-methylumbelliferyl. Thus, the sulfatase response was more robust and sensitive than that of the $\beta$-galactosidase reporter (Whangsuk et al. 2016).

In one study, a DNA fragment comprising the open reading frame of mpd (methyl parathion hydrolase encoding gene) and a cognate regulator from Pseudomonas putida DLL-1, having methyl-parathion (MP) degrading capacity, was constructed. It was cloned by the gene shotgun method in the pBR1MCS-2 vector to develop a recombinant plasmid pBBR-mpd. A genetically engineered microorganism, CDSpBBR-mpd, degrading both carbofuran and MP, was built by transforming the above DNA fragment into the carbofuran-degrading strain Sphingomonas sp. CDS-1. It preserved stability and maintained high MP hydrolase activities, making it a promising genetically engineered microorganism for bioremediation (Zhi Liu et al. 2006).

Another biosensor was developed using constitutively expressed redox-sensitive GFP (roGFP2) in E. coli, which is induced by chemicals. This work shows that just a few minutes are sufficient to detect oxidation by using $E$. coli-roGFP2, compared to the traditional oxidative microbial biosensor. The minimum quantity (in ppm) detected was $1.0 \times 10^{-7}$ (arsenite), $1.0 \times 10^{-4}$ (naphthalene), $1.0 \times 10^{-4}\left(\mathrm{Cu}^{2+}\right), 3.8 \times$

$10^{-4}\left(\mathrm{H}_{2} \mathrm{O}_{2}\right), 1.0 \times 10^{-3}\left(\mathrm{Cd}^{2+}\right), 1.0 \times 10^{-3}\left(\mathrm{Zn}^{2+}\right), 1.0 \times 10^{-2}$ (menadione), 1.0 (triphenyltin), 1.56 (zinc pyrithione), 3.1 (selenite) and $6.3\left(\mathrm{~Pb}^{2+}\right)$, respectively. The induction of oxidation occurred through heavy metals, while the sigmoid curve was identified for another compound, which is concentration-dependent. A study demonstrates that in vitro roGFP2 and in vivo GSH concentrations with E. coli-roGFP2 justified that roGFP2 is recognised as sensitive to redox potential and thiol modification stimulated by xenobiotics (Carlos et al. 2010).

Biosensors generated with the use of cyanobacteria might be able to detect herbicides and other xenobiotic compounds. The Synechocystis sp. strain PCC6803 was chromosomally labelled with the luc gene to develop a new strain of a bioluminescent cyanobacterium. Successful expression showed that it produces bioluminescence, and bioassays revealed that a new luminescent biosensor was established, which responded to a variation of xenobiotics and herbicides (Shao et al. 2002). This review indicates that the fusions of a reporter gene into microbial biosensors for the identification of xenobiotics in the environment are valuable for examining the bioavailability of the inducing contaminants. Biosensors are considered to provide new chances for the rapid screening of contaminated sites or the detection of potential environmental damage (Shao et al. 2002; Sang et al. 2004).

\section{Potential environmental effects and biosafety concerns}

With advancements in synthetic biology, newer biosensors with advanced features and characteristics can be developed and applied for in situ monitoring of environmental contaminants. While considering synthetic biology-based biosensors, it is imperative to assess the possible risks in terms of their interaction with the environment and how these can be mitigated. The whole-cell bacterial biosensors are classified as genetically modified organisms (GMO's), thus raised pertinent questions about potential interaction with commensals, nontarget organisms and other biomolecules. Unlike other forms of polluting substances such as chemical spills, it is not easy to contain or control the self-replicating organism released into the environment. The engineered microorganism with even known biology and mechanism would be difficult to predict the unexpected and unwanted environmental effects in advance. 
Moreover, engineered organisms would not fit into the natural environment, leading to finding them suitable ecological niche and modifying accordingly by swapping genes with other organisms. Horizontal Gene Transfer (HGT) mechanism is a common and uncontrollable trait among bacterial systems (Thomas et al., 2005) that relies on acquiring foreign genes. The primary issue with HGT is concerned with transferring genetic sequences from the genetically modified bacteria to the indigenous microorganism resulting in altering their genome and, ultimately, their ecological niche (Heuer and Smalla, 2007). Even if the engineered microorganism does not survive in the natural environment, the free synthesised DNA in the modified microorganism can pose an environmental risk as it can be actively assimilated by many other bacteria (Thomas and Nielsen, 2005), unicellular and multicellular eukaryotes (Boschetti et al., 2012). In this context, it is crucial to prevent the transfer of modified (recombinant and synthetic) DNA to the environment and other organisms via HGT (Wright et al., 2013). This prevents the overburdening of polluting the environment with engineered microorganisms. The antibiotic resistance genes have been utilised in the plasmid for selecting modified organisms, but this can pose a significant challenge in generating antibiotic-resistant superbugs. Keeping these points in view, it is critical to test the WCBMB extensively on a laboratory or piolet scale before releasing it in the environment.

\section{The future of whole-cell biosensors}

In recent years, increasing pollution has diverted the attention of researchers to mitigate the problem through innovative state-of-the-art techniques. The bacterial community has the smartest system to quickly adapt to new environmental conditions by directly evolving coping mechanisms. Easy adaptation and high robustness make them an ideal platform for scalable biosensing devices. The ongoing industrialisation and the resulting emergence of new pollutants lead the way to a better understanding of reporter genes and to an improved detection and degradation of these pollutants. Furthermore, miniaturized bioreporter assays have potential for the monitoring of toxicants in environmental samples. This, however, calls for the creation of a metagenomics library consisting of large insert fragments, generating a wealth of possibilities for screening novel genes to construct genetically modified microorganisms (Xing et al. 2020) that will additionally provide better specificity to the concerned biosensor. Further, the comprehensive study of bacterial whole genome sequences (Ali et al., 2018; Behare et al., 2020) and pan proteome investigations (Pragya et al., 2017; Nataraj et al., 2020) allows the determination of crucial genes for the specific niches (Kaur et al., 2017; Ali et al., 2020). Therefore, we suggest two crucial concerns that demand attention, namely response period and detection limit.

Although the whole-cell-based microbial biosensor can outperform the conventional chemical-based sensor, continuous efforts are still being made to increase the applicability of these sensors. Another concern is the increase in pollution levels in the environment, increasing the possibility of co-contaminated sites with multiple pollutants. It could be envisaged that fabricating multifunctional biosensors by incorporating a combination of numerous regulatory proteins provides the explicit advantage of the simultaneous sensing of various contaminants (Hou et al. 2015). Another prime focus for the use of whole-cell microbial biosensors relies on the construction of multifunctional biosensors that will be able to sustain harsh environmental conditions with high temperatures, acidity, alkalinity and salinity. Thus, different microbial species, such as extremophiles, thermophiles, alkalophiles or halophiles, could be useful as host cells for constructing whole-cell microbial biosensors. The presence of different toxic compounds in the samples either inhibit or decrease the activity of microbial cells and can be mitigated by self-powered biosensors.

Although microbial biosensors have tremendous potential, only a few applications are being implemented within ecosystems, primarily because of legislative restrictions that are generating ethical issues as the components of the whole cell-based biosensor may interact, and thus interfere, with the host metabolism. With the recent advancement in sequencing methods, robust characterisations can now be performed to better elucidate and understand the fate, activities and interactions of this microbial biosensor strain under real-world scenarios to stimulate and enable future full-scale field applications. Mainly the transcriptomic approaches can be used to identify the promoter/operator pair better to be rearranged into the bacterial system for the desired functions.

The complex biological systems can pose a significant hurdle in engineering biosystems with desired features, as exemplified by the presence of interconnected transcriptional regulatory networks that often produce unpredictable results. Transcriptional biosensing dictates the microbial cells to act following the surrounding environmental signals. The introduction of synthetic biology provides novel avenues for creating a manipulated sensing system based on the re-programming genomes and genetic circuits, in addition to tuning

Page 16/32 
environment-responsive transcriptional regulators in a bacterial order. Continuous efforts are being made to meet the advanced sensitivity, threshold, dynamic and optical range of the microbial modulating system, thus introducing biocomputational tools, including Boolean logic gates, and programmable cellular computation with scalable signal-processing capacity, benefiting the revolutionary biosensing technique.

However, the new scenario is changing as scientists begin to incorporate decision tree models to identify numerous xenobiotics and pattern-learning algorithms via specific light emission profiles. Moreover, machine learning tools become an intricate tool to design biosystems with optimised performance and desired properties because of their power of better predictability (Volk et al. 2020). Despite all the advantages of microbial biosensors, it is crucial to investigate the portability and miniaturisation of signal detection systems to increase the use in the field. It is a diverse, fast-growing field that can be coupled to other high-throughput technologies such as microfluidics, which provides an opportunity to detect multiple analytes at the same time with high sensitivity and long-term preservation (Roggo and Meer 2017). Another hardware platform, such as smartphone-based whole-cell microbial biosensors harbouring engineered bacteria, allows induced response to quantifiable signals.

Moreover, the integration of microfluidic devices for sample attainment and smartphones for imaging and data calculation provides a laboratory-independent sensing micro-machined platform (Yang et al. 2016). Portable, lightweight device systems, such as a paper strips or a card, are promising tools and could be implied in on-site environmental monitoring. Such technologies will evolve rapidly into more programmed, compressed and wireless devices for the real-time detection of a wide range of environmentally relevant contaminants, indicating a keener perception of genetically engineered whole-cell microbial-derived biosensors for broader performance. This review summarises the vast range of analyses using various genetic elements of an operon, such as promoter/operator, reporter genes and metal sensitiveness, and their on-site degradation for the establishment of biosensors. This simultaneous detection and deterioration of environmental pollutants resulted in an innovative and multidisciplinary approach.

\section{References}

Abby M, Beaudette A, Lee H, Trevors T (2003) Polychlorinated biphenyl (PCB) degradation and persistence of a gfp-marked Ralstonia eutropha H850 in PCB-contaminated soil. Appl Microbiol Biotechnol 63:222-230. https://doi.org/10.1007/s00253-003-1380-x।

Ali S A, Kumar S, Mohanty A K, Behare P (2018) Draft genome sequence of Lactobacillus fermentum NCDC 400, isolated from a traditional Indian dairy product. Genome announcements, 6(2).

Ali S A, Singh P, Tomar S K, Mohanty A K, Behare P (2020) Proteomics fingerprints of systemic mechanisms of adaptation to bile in Lactobacillus fermentum. Journal of proteomics, 213, 103600.

Ali S A, Kaur G, Kaushik J K, Malakar D, Mohanty A K, Kumar S (2017) Examination of pathways involved in leukemia inhibitory factor (LIF)-induced cell growth arrest using label-free proteomics approach. Journal of proteomics, 168, 37-52. 10.1016/j.jprot.2017.08.008

Aleksic J, Bizzari F, Cai Y, Davidson B, De Mora K, Ivakhno S, Seshasayee L, Nicholson J, Wilson J, Elfick A et al (2007) Development of a novel biosensor for the detection of arsenic in drinking water. IET Synth Biol 1:87-90. doi: 10.1049/iet-stb:20060002

Alexander, M (1985). Biodegradation of organic chemicals. Environ Sci Technol 19:106-111. doi: 10.5772/56194

Anderson, J.C., Voigt, C.A. and Arkin, A.P., 2007. Environmental signal integration by a modular AND gate. Molecular systems biology, 3(1), p.133.

Anosova, I., Kowal, E.A., Dunn, M.R., Chaput, J.C., Van Horn, W.D. and Egli, M., 2015. The structural diversity of artificial genetic polymers. Nucleic acids research, 44(3), pp.1007-1021.

Antonucci I, Gallo G, Limauro D, Contursi P, Ribeiro L, Blesa A, Berenguer J, Bartolucci S, Fiorentino G (2018) Characterization of a promiscuous cadmium and arsenic resistance mechanism in Thermus thermophilus HB27 and potential application of a novel bioreporter system. Microb Cell Fact 17:78. https://doi.org/10.1186/s12934-018-0918-7 
Arias-Barreiro R, Okazaki K, Koutsaftis A, Inayat-Hussain S, Tani A, Katsuhara M, Kimbara K, Mori I (2010) A bacterial biosensor for oxidative stress using the constitutively expressed redox-sensitive protein roGFP2. Sensors 10:6290-6306. doi: 10.3390/s100706290

Baba, T., Ara, T., Hasegawa, M., Takai, Y., Okumura, Y., Baba, M., Datsenko, K.A., Tomita, M., Wanner, B.L. and Mori, H., 2006. Construction of Escherichia coli K-12 in-frame, single-gene knockout mutants: the Keio collection. Molecular systems biology, 2(1), pp.2006-0008

Bachmann A, Walet P, Wijnen P, De Bruin W, Huntjens L, Roelofsen W and Zehnder J (1988). Biodegradation of alpha-and betahexachlorocyclohexane in a soil slurry under different redox conditions. Appl. Environ. Microbiol 54:143-149. doi: 10.1128/aem.54.1.143149.1988

Barrios-Estrada C, de Jesús Rostro-Alanis M, Muñoz-Gutiérrez D, lqbal M, Kannan S. Parra-Saldívar R (2018) Emergent contaminants: endocrine disruptors and their laccase-assisted degradation-a review. Sci Total Environ. 612:1516-1531.

https://doi.org/10.1016/j.scitotenv.2017.09.013

Behare P V, Ali S A, McAuliffe O (2020) Draft Genome Sequences of Fructobacillus fructosus DPC 7238 and Leuconostoc mesenteroides DPC 7261, Mannitol-Producing Organisms Isolated from Fructose-Rich Honeybee-Resident Flowers on an Irish Farm. Microbiology Resource Announcements, 9(50).

Bensasson, D., Boore, J.L. and Nielsen, K.M., 2004. Genes without frontiers?. Heredity, 92(6), pp.483-489).

Bereza-Malcolm L, Aracic S, Franks E (2016) Development and application of a synthetically-derived lead biosensor construct for use in gram-negative bacteria. Sensors 16:2174. doi: 10.3390/s16122174

Bereza-Malcolm L, Aracic S, Kannan R, Mann G, Franks E (2017) Functional characterization of gram-negative bacteria from different genera as multiplex cadmium biosensors. Biosens Bioelectron 94:380-387. doi:10.1016/j.bios.2017.03.029

Berset Y, Merulla D, Joublin A, Hatzimanikatis V, Van Der Meer R (2017) Mechanistic modeling of genetic circuits for ArsR arsenic regulation. ACS Synth Biol 6:862-874. https://doi.org/10.1021/acssynbio.6b00364

Bezerra, A.R., Guimarães, A.R. and Santos, M.A., 2015. Non-standard genetic codes define new concepts for protein engineering. Life, 5(4), pp.1610-1628.

Bharagava N, Mishra S (2018) Hexavalent chromium reduction potential of Cellulosimicrobium sp. isolated from common effluent treatment plant of tannery industries. Ecotoxicol Environ Safety 147:102-109. https://doi.org/10.1016/j.ecoenv.2017.08.040

Bilal M, Adeel M, Rasheed T, Zhao Y, Iqbal M (2019) Emerging contaminants of high concern and their enzyme-assisted biodegradation-A review. Environ Int 124:336-353. https://doi.org/10.1016/j.envint.2019.01.011

Bilal M, Asgher M, Parra-Saldivar R, Hu H, Wang W, Zhang X, Iqbal M (2017) Immobilized ligninolytic enzymes: an innovative and environmental responsive technology to tackle dye-based industrial pollutants-a review. Sci Total Environ 576:646-659. doi: 10.1016/j.scitotenv.2016.10.137

Biran I, Rissin M, Ron Z, Walt R (2003) Optical imaging fiber-based live bacterial cell array biosensor. Anal Biochem 315:106-113. https://doi.org/10.1016/S0003-2697(02)00700-5

Boldt S, Sorensen J, Karlson U, Molin S, Ramos C (2004) Combined use of different Gfp reporters for monitoring single-cell activity of a genetically modified PCB degrader in the rhizosphere of Alfalfa. FEMS Microbiol Ecol 48:139-148.

https://doi.org/10.1016/j.femsec.2004.01.002

Boschetti C, Carr A, Crisp A, Eyres I, Wang-Koh Y, Lubzens E, Barraclough G, Micklem G and Tunnacliffe A (2012). Biochemical diversification through foreign gene expression in bdelloid rotifers. PLoS Genet 8:p.e1003035. doi.org/10.1371/journal.pgen.1003035

Branco R, Cristóvão A, Morais PV (2013) Highly sensitive, highly specific whole-cell bioreporters for the detection of chromate in environmental samples. PLoS One 8, e5005. https://doi.org/10.1371/journal.pone.0054005

Brophy A, Voigt A (2014) Principles of genetic circuit design. Nat Methods 11:508-520. https://doi.org/10.1038/nmeth.2926

Cameron E, Collins J (2014) Tunable protein degradation in bacteria. Nat Biotechnol 32:1276-1281. https://doi.org/10.1038/nbt.3053

Page 18/32 
Chalfie M, Tu Y, Euskirchen G, Ward W, Prasher C (1994) Green fluorescent protein as a marker for gene expression. Science 263:802-805. doi:10.1126/science.8303295

Chamas, A., Moon, H., Zheng, J., Qiu, Y., Tabassum, T., Jang, J.H., Abu-Omar, M., Scott, S.L. and Suh, S., 2020. Degradation rates of plastics in the environment. ACS Sustainable Chemistry \& Engineering, 8(9), pp.3494-3511.

Chandrasekhar V, Das S, Yadav R, Hossain S, Parihar R, Subramaniam G, Sen P (2012) Novel chemosensor for the visual detection of copper (II) in aqueous solution at the ppm level. Inorg Chem 51:8664-8666. https://doi.org/10.1021/ic301399a

Chang J, Voyvodic L, Zúñiga A, Bonnet J (2017) Microbially derived biosensors for diagnosis, monitoring and epidemiology. Microb Biotechnol 10:1031-1035. doi: 10.1111/1751-7915.12791

Chang, T.M.S. and Prakash, S., 2001. Procedures for microencapsulation of enzymes, cells and genetically engineered microorganisms. Molecular Biotechnology, 17(3), pp.249-260. doi.org/10.1385/MB:17:3:249

Chen B, Lee L, Heng C, Chua N, Teo S, Choi J, Leong J, Foo L, Chang W (2018) Synthetic biology toolkits and applications in Saccharomyces cerevisiae. Biotechnol Adv 36:1870-1881. https://doi.org/10.1016/j.biotechadv.2018.07.005

Chen H, Lin C, Guo H, Yeh, C (2017) Development of a pigment-based whole-cell biosensor for the analysis of environmental copper. RSC Adv 7:29302-29305. https://doi.org/10.1039/C7RA03778C

Chen Y, Ho M, Shis L, Gupta C, Long J, Wagner S, Ott W, Josić K, and Bennett R (2018) Tuning the dynamic range of bacterial promoters regulated by ligand-inducible transcription factors. Nat Commun 9:64. https://doi.org/10.1038/s41467-017-02473-5

Chien K, Shih H (2007) An empirical study of the implementation of green supply chain management practices in the electrical and electronic industry and their relation to organizational performances. Int J Environ Sci Tech 4:383-394.

Chin, J.W., 2014. Expanding and reprogramming the genetic code of cells and animals. Annual review of biochemistry, 83, pp.379-408.

Cocârţă M, Stoian A, and Karademir A (2017) Crude oil contaminated sites: evaluation by using risk assessment approach. Sustainability 9:1365. doi: 10.3390/su9081365

Coelho C, Branco R, Natal-da-Luz T, Sousa P, and Morais V (2015) Evaluation of bacterial biosensors to determine chromate bioavailability and to assess ecotoxicity of soils. Chemosphere 128:62-69. https://doi.org/10.1016/j.chemosphere.2014.12.026

Dana V, Kuiken T, Rejeski D, and Snow A (2012) Four steps to avoid a synthetic-biology disaster. Nature 483:29.

https://doi.org/10.1038/483029a

Daunert S, Barrett G, Feliciano S, Shetty S, Shrestha S, and Smith-Spencer W (2000) Genetically engineered whole-cell sensing systems: coupling biological recognition with reporter genes. Chem Rev 100:2705-2738. doi:10.1021/cr990115p

Davies J and Davies D (2010). Origins and evolution of antibiotic resistance. Microbiol Molecu Boil Revie 74:417-433. doi:

10.1128/MMBR.00016-10

Edward Raja C, Selvam S (2011) Construction of green fluorescent protein based bacterial biosensor for heavy metal remediation. Int J Environ Sci Tech 8:793-798. https://doi.org/10.1007/BF03326262

Elcin E, Öktem A (2018) Whole-cell fluorescent bacterial bioreporter for arsenic detection in water. Int J Environ Sci Technol 16:5489-5500. https://doi.org/10.1007/s13762-018-2077-0

Elcin E, Öktem A (2020) Immobilization of fluorescent bacterial bioreporter for arsenic detection. J Environ Health Sci Eng 18:137-148. https://doi.org/10.1007/s40201-020-00447-2

Erbe L, Adams C, Taylor B, and Hall M (1996) Cyanobacteria carrying an smt-lux transcriptional fusion as biosensors for the detection of heavy metal cations. J Indust Microbiol 17:80-83. https://doi.org/10.1007/BF01570047

Fekih B, Zhang C, Li P, Zhao Y, Alwathnani A, Saquib Q, Rensing C, and Cervantes C (2018) Distribution of arsenic resistance genes in prokaryotes. Front Microbiol 9:2473. doi: 10.3389/fmicb.2018.02473

Page 19/32 
Friedland, A.E., Lu, T.K., Wang, X., Shi, D., Church, G. and Collins, J.J., 2009. Synthetic gene networks that count. science, 324(5931), pp.1199-1202.

Gallagher, R.R., Patel, J.R., Interiano, A.L., Rovner, A.J. and Isaacs, F.J., 2015. Multilayered genetic safeguards limit growth of microorganisms to defined environments. Nucleic acids research, 43(3), pp.1945-1954.

Gander, M.W., Vrana, J.D., Voje, W.E., Carothers, J.M. and Kalvins, E., 2016. Robust digital logic circuits in eukaryotic cells with CRISPR/dCas9 NOR gates. bioRxiv, p.041871. doi.org/10.1101/041871

Gautam P, Suniti S, Kumari A, Madathil, D, and Nair B (2012) A review on recent advances in biosensors for detection of water contaminaion. Int J Environ Sci 2:1565-1574.

Gerdes, K., Poulsen, L.K., Thisted, T., Nielsen, A.K., Martinussen, J. and Andreasen, P.H., 1990. The hok killer gene family in gram-negative bacteria. New Biologist, 2(11), pp.946-956.

Gibson, D.G., Glass, J.I., Lartigue, C., Noskov, V.N., Chuang, R.Y., Algire, M.A., Benders, G.A., Montague, M.G., Ma, L., Moodie, M.M. and Merryman, C., 2010. Creation of a bacterial cell controlled by a chemically synthesized genome. science, 329(5987), pp.52-56

Gireesh-Babu P, Chaudhari A (2012) Development of a broad-spectrum fluorescent heavy metal bacterial biosensor. Mol Biol Rep 39:11225-11229. doi: 10.1007/s11033-012-2033-x.

Goni-Moreno A, Nikel I (2019) High-performance biocomputing in synthetic biology-integrated transcriptional and metabolic circuits. Front Bioeng Biotechnol 7:40. https://doi.org/10.3389/fbioe.2019.00040

Gronow M (1984) Biosensors. Trends Biochem Sci 9:336-340. https://doi.org/10.1007/s10534-004-5787-3

Gueu S, Yao B, Adouby K, Ado G (2007) Kinetics and thermodynamics study of lead adsorption on to activated carbons from coconut and seed hull of the palm tree. Int J Environ Sci Tech 4:11-17. https://doi.org/10.1007/BF03325956

Gui Q, Lawson T, Shan S, Yan L, and Liu Y (2017) The application of whole cell-based biosensors for use in environmental analysis and in medical diagnostics. Sensors 17:1623. doi:10.3390/s17071623

Gupta S, Sarkar S, Katranidis A, Bhattacharya J (2019) Development of a Cell-Free Optical Biosensor for Detection of a Broad Range of Mercury Contaminants in Water: A Plasmid DNA-Based Approach. ACS omega 4:9480-9487. https://doi.org/10.1021/acsomega.9b00205

Gursahani H, Gupta G (2011) Decolourization of textile effluent by a thermophilic bacteria Anoxybacillus rupiensis. J Pet Environ Biotechnol 2:1-4. doi: 10.4172/2157-7463.1000111

Handa K, Jindal R (2019) Chronic toxicity of hexavalent chromium affects the morphology and behaviour of Ctenopharyngodon idellus (Cuvier and Valenciennes). Int J Fisheri Aqua Stud 7:46-51.

Hansen H, Sorensen SJ (2001) The use of whole-cell biosensors to detect and quantify compounds or conditions affecting biological systems. Microb Ecol 42:483-494. doi: 10.1007/s00248-001-0025-9

Hayat MT, Nauman M, Nazir N, Ali S. and Bangash N (2019) Environmental Hazards of Cd: Past, Present, and Future. In: Cd Toxicity and Tolerance in Plants Academic Press, pp 163-183.

Hayes, F. and Van Melderen, L., 2011. Toxins-antitoxins: diversity, evolution and function. Critical reviews in biochemistry and molecular biology, 46(5), pp.386-408

Hayes, F., 2003. Toxins-antitoxins: plasmid maintenance, programmed cell death, and cell cycle arrest. Science, 301(5639), pp.1496-1499.

Hendrix, C., Rosemeyer, H., Verheggen, I., Van Aerschot, A., Seela, F. and Herdewijn, P., 1997. 1', 5'-Anhydrohexitol oligonucleotides: synthesis, base pairing and recognition by regular oligodeoxyribonucleotides and oligoribonucleotides. Chemistry-A European Journal, 3(1), pp.110-120.

Hernandez-Vargas G, Sosa-Hernández J, Saldarriaga-Hernandez S, Villalba-Rodríguez A, Parra-Saldivar R, Iqbal H (2018) Electrochemical biosensors: A solution to pollution detection with reference to environmental contaminants. Biosensors 8:29. doi: 10.3390/bios8020029 
Heuer, H. and Smalla, K., 2007. Horizontal gene transfer between bacteria. Environ. Biosafe. Res 6:3-13. doi: 10.1051/ebr:2007034

Hoch, J.A. and Silhavy, T.J. eds., 1995. Two-component signal transduction (Vol. 2). Washington, DC: ASM press.

Holzinger M, Le Goff A, Cosnier S (2014) Nanomaterials for biosensing applications: a review. Frontiers in chemistry, 2, 63.

Hou Q, Ma A, Wang T, Lin J, Wang H, Du B, Zhuang X, Zhuang G (2015) Detection of bioavailable cadmium, lead, and arsenic in polluted soil by tailored multiple Escherichia coli whole-cell sensor set. Analytical and bioanalytical chemistry 407:6865-71. doi: 10.1007/s00216015-8830-z

Hu Q, Li L, Wang Y, Zhao W, Qi H, Zhuang G (2010) Construction of WCB-11: A novel phiYFP arsenic-resistant whole-cell biosensor. J Environ Sci 22:1469-74. https://doi.org/10.1016/S1001-0742(09)60277-1

Huang W, Yang H, Sun W, Liao C (2015) Development of a set of bacterial biosensors for simultaneously detecting arsenic and mercury in groundwater. Environ Sci Pollut Res Int 22:10206-10213. https://doi.org/10.1007/s11356-015-4216-1

Hui Y, Guo Y, Liu L, Zheng Q, Gao X, and Zhang W (2020) Construction of a RFP-lacZa bicistronic reporter system and its application in lead biosensing. PloS one15:e0228456. https://doi.org/10.1371/journal.pone.0228456

Hurdebise Q, Tarayre C, Fischer C, Colinet G, Hiligsmann S, and Delvigne F (2015) Determination of zinc, cadmium and lead bioavailability in contaminated soils at the single-cell level by a combination of whole-cell biosensors and flow cytometry. Sensors 15:8981-8999. doi: $10.3390 /$ s150408981

Hutchins R, Tomson B, Wilson T and Ward H (1984). Microbial removal of wastewater organic compounds as a function of input concentration in soil columns. Applied and environmental microbiology, 48:1039-1045.

Hynninen A, Tõnismann K, Virta M (2010) Improving the sensitivity of bacterial bioreporters for heavy metals. Bioeng Bugs 1:132-1138. doi: 10.4161/bbug.1.2.10902

Jain K. and Magrath T (1991) A chemiluminescent assay for quantitation of $\beta$-galactosidase in the femtogram range: application to quantitation of $\beta$-galactosidase in lacZ-transfected cells. Anal Biochem 199:119-124. doi: 10.1016/0003-2697(91)90278-2

Jia X, Bu R, Zhao T, Wu K (2019) Development of a sensitive and specific whole-cell biosensor for arsenic detection. Appl Environ Microbiol 85:e00694-19. doi: 10.1128/AEM.00694-19

Jia X, Zhao T, Liu Y, Bu R, Wu K (2018) Gene circuit engineering to improve the performance of a whole-cell lead biosensor. FEMS Microbiol. Lett., 365, fny157. https://doi.org/10.1093/femsle/fny157

Jiang B, Li G, Xing Y, Zhang D, Jia J, Cui Z, Luan X, Tang H (2017) A whole-cell bioreporter assay for quantitative genotoxicity evaluation of environmental samples. Chemosphere 184:384-392. doi: 10.1016/j.chemosphere.2017.05.159

Jiang B, Zhu D, Song Y, Zhang D, Liu Z, Zhang X, Huang E, Li G (2015) Use of a whole-cell bioreporter, Acinetobacter baylyi, to estimate the genotoxicity and bioavailability of chromium (VI)-contaminated soils. Biotechnol Lett 37:343-348. doi: 10.1007/s10529-014-1674-3

Joshi, N., Wang, X., Montgomery, L., Elfick, A. and French, C.E., 2009. Novel approaches to biosensors for detection of arsenic in drinking water. Desalination, 248(1-3), pp.517-523.

Kang G, Choi S, Cha J (2006) Enhanced biodegradation of toxic organophosphate compounds using recombinant Escherichia coli with sec pathway-driven periplasmic secretion of organophosphorus hydrolase. Biotechnol Prog 22:406-410. doi: 10.1021/bp050356k

Kang Y, Lee W, Jang G, Kim G, Yoon Y (2018) Modulating the sensing properties of Escherichia coli-based bioreporters for Cd and mercury. Appl Microbiol Biotechnol 102:4863-4872. doi: 10.1007/s00253-018-8960-2

Kang Y, Lee W, Kim S, Jang G, Kim G, Yoon Y (2018) Enhancing the copper-sensing capability of Escherichia coli-based whole-cell bioreporters by genetic engineering. Appl Microbial Biotechnol 102:1513-1521. doi: 10.1007/s00253-017-8677-7

Karbassi R, Nouri J, Mehrdadi N, Ayaz O (2008) Flocculation of heavy metals during mixing of freshwater with Caspian Sea water. Environ Geo 53:1811-1816. https://doi.org/10.1007/s00254-007-0786-7

Page 21/32 
Kaur G, Ali S A, Kumar S, Mohanty A K, Behare P (2017) Label-free quantitative proteomic analysis of Lactobacillus fermentum NCDC 400 during bile salt exposure. Journal of proteomics, 167, 36-45.

Kaur G, Ali S A, Pachauri S, Malakar D, Kaushik J K, Mohanty A K, Kumar S (2017) Buffalo leukemia inhibitory factor induces differentiation and dome-like secondary structures in COS-1 cells. Cytogenetic and genome research, 151(3), 119-130.

Kim J, Lim W, Jeong H, Lee J, Lee W, Kim T, Lee J (2016) Development of a highly specific and sensitive cadmium and lead microbial biosensor using synthetic CadC-T7 genetic circuitry. Biosens Bioelectron 79:701-708. doi: 10.1016/j.bios.2015.12.101

Komorowicz I, Barałkiewicz D (2016) Determination of total arsenic and arsenic species in drinking water, surface water, wastewater, and snow from Wielkopolska, Kujawy-Pomerania, and Lower Silesia provinces, Poland. Environ Monit Assess 188:504. https://doi.org/10.1007/s10661-016-5477-y

Kumar S, Verma N, Singh K (2017) Development of Cd specific recombinant biosensor and its application in milk samples. Sens Actuators B: Chem 240:248-254. https://doi.org/10.1016/j.snb.2016.08.160

Lacey F, Ye D, Ruffing M (2019) Engineering and characterization of copper and gold sensors in Escherichia coli and Synechococcus sp. PCC 7002. Appl Microbiol Biotechnol 103:2797-2808. https://doi.org/10.1007/s00253-018-9490-7

Lajoie, M.J., Rovner, A.J., Goodman, D.B., Aerni, H.R., Haimovich, A.D., Kuznetsov, G., Mercer, J.A., Wang, H.H., Carr, P.A., Mosberg, J.A. and Rohland, N., 2013. Genomically recoded organisms expand biological functions. science, 342(6156), pp.357-360.

Lajoie, M.J., Söll, D. and Church, G.M., 2016. Overcoming challenges in engineering the genetic code. Journal of molecular biology, 428(5), pp.1004-1021.

Lalithakumari, D., 2011. Microbes: a tribute to clean environment. University of Madras, Chennai.

Lee W, Kim H, Kang Y, Lee Y, Yoon Y (2019) A biosensor platform for metal detection based on enhanced green fluorescent protein. Sensors 19:1846. https://doi.org/10.3390/s19081846

Lehmann M, Riedel K, Adler K, Kunze G (2000) Amperometric measurement of copper ions with a deputy substrate using a novel Saccharomyces cerevisiae sensor. Biosens Bioelectron 15:211-219. doi: 10.1016/S0956-5663(00)00060-9

Lei Y, Mulchandani P, Chen W, Wang J, Mulchandani A (2004) Arthrobactersp. JS443-Based Whole Cell Amperometric Biosensor for pNitrophenol. Electroanalysis Int J Devoted Fundamen Prac Aspects Electroanal 16:2030-2034. https://doi.org/10.1002/elan.200403067

Lejon D, Martins J, Leveque J, Spanini L, Pascault N, Landry M, Milloux M, Nowak V, Chaussod R, Ranjard L (2008) Copper dynamics and impacts on microbial communities in soils of variable organic status. Environ Sci Technol 42:2819-2825.

https://doi.org/10.1021/es071652r

Li C, Zhou K, Qin W, Tian C, Qi M, Yan X, Han W (2019) A Review on Heavy Metals Contamination in Soil: Effects, Sources, and Remediation Techniques, Soil Sediment Contam. Int J 28:380-394. https://doi.org/10.1080/15320383.2019.1592108

Liss, M., Daubert, D., Brunner, K., Kliche, K., Hammes, U., Leiherer, A. and Wagner, R., 2012. Embedding permanent watermarks in synthetic genes. PloS one, 7(8), p.e42465

Liu J, Olsson G, Mattiasson B (2004) Short-term BOD (BODst) as a parameter for online monitoring of biological treatment process Part I. A novel design of BOD biosensor for easy renewal of bio-receptor. Biosen Bioelect 20:562-570. https://doi.org/10.1016/j.bios.2004.03.008

Liu X, Germaine KJ, Ryan D, Dowling DN (2010) Whole-cell fluorescent biosensors for bioavailability and biodegradation of polychlorinated biphenyls. Sensors 10:1377-1398. doi: 10.3390/s100201377

Liu Z, Hong Q, Xu H, Jun W, Li P (2006) Construction of a genetically engineered microorganism for degrading organophosphate and carbamate pesticides. Int Biodeterior Biodegrade 58:65-69. https://doi.org/10.1016/j.ibiod.2006.07.009

Maduraiveeran G, Jin W (2017) Nanomaterials based electrochemical sensor and biosensor platforms for environmental applications. Trends Environ Anal Chem 13:10-23. https://doi.org/10.1021/ac5039863 
Mahbub R, Krishnan K, Naidu R, Megharaj M (2017) Development of a whole cell biosensor for the detection of inorganic mercury. Environ Technol Innov 8:64-70. https://doi.org/10.1016/j.eti.2017.04.003

Mahmood Q, Asif M, Shaheen S, Hayat MT, Ali S (2019) Cd Contamination in Water and Soil, In Cd Toxicity and Tolerance in Plants (pp. 141-161). Academic Press.

Maret W, Wedd A eds., 2014. Binding, transport and storage of metal ions in biological cells. Royal Society of Chemistry 2

Martinez R, Heil R, Charles TC (2019) An engineered GFP fluorescent bacterial biosensor for detecting and quantifying silver and copper ions. BioMetals 32:265-272. https://doi.org/10.1007/s10534-019-00179-3

Merulla D, van der Meer R (2015) Regulatable and modulable background expression control in prokaryotic synthetic circuits by auxiliary repressor binding sites. ACS Synth Biol 5:36-45. https://doi.org/10.1021/acssynbio.5b00111

Mittal D, Kaur G, Ali S A (2020) Nanoparticles based sustainable agriculture and food science: Recent Advances and Future Outlook. Frontiers in Nanotechnology, 2, 10.

Mukai, T., Lajoie, M.J., Englert, M. and Söll, D., 2017. Rewriting the genetic code. Annual review of microbiology, 71, pp.557-577.

Mulchandani A, Rogers R (1998) Enzyme and micriobial biosensors: Techniques and protocols. NJ, USA.

Mulchandani P, Hangarter M, Lei Y, Chen W, Mulchandani A (2005) Amperometric microbial biosensor for p-nitrophenol using Moraxella sp.-modified carbon paste electrode. Biosens Bioelectron 21:523-527. doi: 10.1016/j.bios.2004.11.011

Naether J, Slawtschew S, Stasik S, Engel M, Olzog M, Wick Y, Timmis N, Heipieper J (2013) Adaptation of the hydrocarbonoclastic bacterium Alcanivorax borkumensis SK2 to alkanes and toxic organic compounds: a physiological and transcriptomic approach. Appl Environ Microbiol 79:4282-4293. doi: 10.1128/AEM.00694-13

Nataraj B H, Ali S A, Behare P V, Yadav H (2020) Postbiotics-parabiotics: the new horizons in microbial biotherapy and functional foods. Microbial cell factories, 19(1), 1-22.

Ng P, Palombo A, Bhave M (2012) Identification of a copper-responsive promoter and development of a copper biosensor in the soil bacterium Achromobacter sp. A022. World J Microbiol Biotechnol 28:2221-2228. doi: 10.1007/s11274-012-1029-y

Nielsen A, Der S, Shin J, Vaidyanathan P, Paralanov V, Strychalski A, Ross D, Densmore D, Voigt A (2016) Genetic circuit design automation. Science 352, p.aac7341. doi: 10.1126/science.aac7341

Nouri J, Lorestani B, Yousefi N, Khorasani N, Hasani AH, Seif S Cheraghi M (2011) Phytoremediation potential of native plants grown in the vicinity of Ahangaran lead-zinc mine (Hamedan, Iran). Environ Earth Sci, 62:639-644. https://doi.org/10.1007/s12665-010-0553-z

Oda Y, Nakamura I, Oki I, Kato T, Shinagawa H (1985) Evaluation of the new system (umu-test) for the detection of environmental mutagens and carcinogens. Mut Res Environ Mut Rel Sub 147:219-229. doi: 10.1016/0165-1161(85)90062-7

Ostrov, N., Landon, M., Guell, M., Kuznetsov, G., Teramoto, J., Cervantes, N., Zhou, M., Singh, K., Napolitano, M.G., Moosburner, M. and Shrock, E., 2016. Design, synthesis, and testing toward a 57-codon genome. Science, 353(6301), pp.819-822.

Paitan, Y., Biran, I., Shechter, N., Biran, D., Rishpon, J. and Ron, E.Z., 2004. Monitoring aromatic hydrocarbons by whole cell electrochemical biosensors. Analytical biochemistry, 335(2), pp.175-183.

Papi, R.M., Chaitidou, S.A., Trikka, F.A. and Kyriakidis, D.A., 2005. Encapsulated Escherichia coli in alginate beads capable of secreting a heterologous pectin lyase. Microbial Cell Factories, 4(1), pp.1-8. doi.org/10.1186/1475-2859-4-35

Paquola C, Asif H, de Bragança Pereira A, Feltes C, Bonatto D, Lima C and Menck M (2018). Horizontal gene transfer building prokaryote genomes: genes related to exchange between cell and environment are frequently transferred. J Molecul Evol 86:190-203.

doi.org/10.1007/s00239-018-9836-x

Park D, Taffet M (2019) Combinatorial sensor design in Caulobacter crescentus for selective environmental uranium detection. ACS Synth Biol 8:807-817. https://doi.org/10.1021/acssynbio.8b00484

Page 23/32 
Park H, Lee H, Oh H, Lee K, Kim K (2002) Detection of aromatic pollutants by bacterial biosensors bearing gene fusions constructed with the dnaK promoter of Pseudomonas sp.DJ-12. J Microbiol Biotechnol 12:417-422.

Park H, Lee K, Chae C, Kim K (2004) Construction of transformant reporters carrying fused genes using pcbc promoter of Pseudomonas sp. DJ-12 for detection of aromatic pollutants. Environ Monit Assess 92:241-251. doi: 10.1023/b:emas.0000014513.00754.95

Park N, Sohn J, Oh B, Kwon O, Rhee K, Hur G, Lee Y, Gellissen G, Kang A (2007) Identification from transcriptome analysis and application to whole cell heavy metal detection systems of the Cd-inducible Hansenula polymorpha SEO1 gene promoter. Appl Environ Microbiol 73:5990-6000.

Petänen T, Romantschuk M (2000) Use of bioluminescent bacterial sensors as an alternative method for measuring heavy metals in soil extracts. Anal Chim Acta 456:55-61. https://doi.org/10.1016/S0003-2670(01)00963-1

Petänen T, Virta M, Karp M, Romantschuk M (2011) Construction and Use of Broad Host Range Mercury and Arsenite Sensor Plasmids in the Soil Bacterium Pseudomonas fluorescens OS8. Microb Ecol 41:360-368. https://doi.org/10.1007/s002480000095

Pola-López A, Camas-Anzueto L, Martínez-Antonio A, Luján-Hidalgo C, Anzueto-Sánchez G, Ruíz-Valdiviezo M, Grajales-Coutiño R, González C (2018) Novel arsenic biosensor "POLA" obtained by a genetically modified E. coli bioreporter cell. Sens Actuators B: Chemi 254:1061-1068. https://doi.org/10.1016/j.snb.2017.08.006

Pragya P, Kaur G, Ali S A, Bhatla S, Rawat P, Lule V, Kumar S, Mohanty A K, Behare P, (2017) High-resolution mass spectrometry-based global proteomic analysis of probiotic strains Lactobacillus fermentum NCDC 400 and RS2. Journal of proteomics, 152, pp.121-130.

Rabbowa E, Rettberg P, Baumstark-Khan C, Horneck G (2002) SOS-LUX- and LAC-FLUORO-TEST for the quantification of genotoxic and/or cytotoxic effects of heavy metal salts. Anal Chimi Acta 456:31-39. https://doi.org/10.1016/S0003-2670(01)01594-X

Rasheed T, Bilal M, Nabeel F, Adeel M, and Iqbal M (2018) Environmentally-related contaminants of high concern: Potential sources and analytical modalities for detection, quantification and treatment. Environ Int 122:52-66.

Renella G, Giagnoni L (2016) Light dazzles from the black box: whole-cell biosensors are ready to inform on fundamental soil biological processes. Chem Biol Tech Agri 3:8. https://doi.org/10.1186/s40538-016-0059-3

Rijavec T, Zrimec J, Oven F, Viršek K, Somrak M, Podlesek Z, Gostinčar C, Leedjärv A, Virta M, Tratnik S, Horvat M (2017) Development of highly sensitive, automatized and portable whole-cell hg biosensor based on environmentally relevant microorganisms. Geomicrobiol J 34:596-605. https://doi.org/10.1080/01490451.2016.1257661

Roberto F, Barnes M, Bruhn F (2002) Evaluation of a GFP reporter gene construct for environmental arsenic detection. Talanta 58:181-188. doi: 10.1016/s0039-9140(02)00266-7

Roggo C, van der Meer JR (2007) Miniaturized and integrated whole cell living bacterial sensors in field applicable autonomous devices. Current opinion in biotechnology 45:24-33. https://doi.org/10.1016/j.copbio.2016.11.023

Ron E (2007) Biosensening environmental pollution. Curr Opin Biotechnol 18:252-256. doi: 10.1016/j.copbio.2007.05.005

Saeidi, N., Wong, C.K., Lo, T.M., Nguyen, H.X., Ling, H., Leong, S.S.J., Poh, C.L. and Chang, M.W., 2011. Engineering microbes to sense and eradicate Pseudomonas aeruginosa, a human pathogen. Molecular systems biology, 7(1), p.521.

Saltepe B, Kehribar S, Su Yirmibeşoğlu S, Şafak Şeker O (2017) Cellular biosensors with engineered genetic circuits. ACS Sens 3:13-26. https://doi.org/10.1021/acssensors.7b00728

Schöning, K.U., Scholz, P., Guntha, S., Wu, X., Krishnamurthy, R. and Eschenmoser, A., 2000. Chemical etiology of nucleic acid structure: the a-threofuranosyl-(3' $\rightarrow$ 2') oligonucleotide system. Science, 290(5495), pp.1347-1351.

Setty, Y., Mayo, A.E., Surette, M.G. and Alon, U., 2003. Detailed map of a cis-regulatory input function. Proceedings of the National Academy of Sciences, 100(13), pp.7702-7707.

Sevilla E, Yuste L, Rojo F (2015) Marine hydrocarbonoclastic bacteria as whole-cell biosensors for n-alkanes. Microb Biotechnol 8:693706. doi: $10.1111 / 1751-7915.12286$

Page 24/32 
Shao Y, Howe J, Porter R, Glover A (2002) Novel cyanobacterial biosensor for detection of herbicides. Appl Environ Microbial 68:50265033. doi: 10.1128/AEM.68.10.5026-5033.2002

Shemer B, Koshet O, Yagur-Kroll S, Belkin S (2017) Microbial bioreporters of trace explosives. Curr Opin Biotechnol 45:113-119. https://doi.org/10.1016/j.copbio.2017.03.003

Siddiki R, Kawakami Y, Ueda S, Maeda I (2011) Solid phase biosensors for arsenic or cadmium composed of a trans factor and cis element complex. Sensors 11:10063-10073. doi: 10.3390/s111110063

Singh N, Gupta K, Kumar A, Sharma B (2017) Synergistic effects of heavy metals and pesticides in living systems. Front Chem 5:70. https://doi.org/10.3389/fchem.2017.00070

Soboleski R, Oaks J, Halford P (2005) Green fluorescent protein is a quantitative reporter of gene expression in individual eukaryotic cells. FASEB J 19:440-442. doi: 10.1096/fj.04-3180fje

Song Y, Jiang B, Tian S, Tang H, Liu Z, Li C, Jia J, Huang E, Zhang X, Li G (2014) A whole-cell bioreporter approach for the genotoxicity assessment of bioavailability of toxic compounds in contaminated soil in China. Environ Pollu 195:178-184.

https://doi.org/10.1016/j.envpol.2014.08.024

Stanton, B.C., Nielsen, A.A., Tamsir, A., Clancy, K., Peterson, T. and Voigt, C.A., 2014. Genomic mining of prokaryotic repressors for orthogonal logic gates. Nature chemical biology, 10(2), pp.99-105. doi.org/10.1038/nchembio.1411

Sun Y, Zhao X, Zhang D, Ding A, Chen C, Huang E, Zhang H (2017) New naphthalene whole-cell bioreporter for measuring and assessing naphthalene in polycyclic aromatic hydrocarbons contaminated site. Chemosphere 186:510-518. doi:

10.1016/j.chemosphere.2017.08.027.

Swindoll M, Aelion M and Pfaender K (1988). Influence of inorganic and organic nutrients on aerobic biodegradation and on the adaptation response of subsurface microbial communities. Appl Environ Microbiol 54:212-217. doi: 10.1128/AEM.54.1.212-217.1988

Tani C, Inoue K, Tani Y, Harun-ur-Rashid M, Azuma N, Ueda S, Yoshida K, Maeda I (2009) Sensitive fluorescent microplate bioassay using recombinant Escherichia coli with multiple promoter-reporter units in tandem for detection of arsenic. J Bioscie Bioengineer 108:414-20. https://doi.org/10.1016/j.jbiosc.2009.05.014

Tauriainen S, Virta M, and Karp M (2000) Detecting bioavailable toxic metals and metalloids from natural water samples using luminescent sensor bacteria. Water Res 34:2661-2666. https://doi.org/10.1016/S0043-1354(00)00005-1

Tauriainen S, Virta M, Chang W, Karp M (1999) Measurement of firefly luciferase reporter gene activity from cells and lysates using Escherichia coli arsenite and mercury sensors. Anal. Biochem 272:191-198. https://doi.org/10.1006/abio.1999.4193

Thomas M and Nielsen M (2005) Mechanisms of, and barriers to, horizontal gene transfer between bacteria. Nat. Revie. Microbial. 3:711721. doi.org/10.1038/nrmicro1234

Trögl J, Chauhan A, Ripp S, Layton C, Kuncová G, Sayler S (2012) Pseudomonas fluorescens HK44: lessons learned from a model wholecell bioreporter with a broad application history. Sensors 12:1544-1571. doi: 10.3390/s120201544

Turpeinen R, Virta M, Haggblom M (2003) Analysis of arsenic bioavailability in contaminated soils. Environ Toxic Chem 22:1-6. https://doi.org/10.1002/etc.5620220101

Van Der Meer R, De Vos M, Harayama S and Zehnder J (1992). Molecular mechanisms of genetic adaptation to xenobiotic compounds. Microbiol Molecul Biol Revie 56:677-694.

Vidal, L., Pinsach, J., Striedner, G., Caminal, G. and Ferrer, P., 2008. Development of an antibiotic-free plasmid selection system based on glycine auxotrophy for recombinant protein overproduction in Escherichia coli. Journal of biotechnology, 134(1-2), pp.127-136

Villacieros M, Whelan C, Mackova M, Molgaard J, Sánchez-Contreras M, Lloret J, Aguirre de Cárcer D, Oruezábal I, Bolanos L, Macek T et al (2005) Polychlorinated biphenyl rhizoremediation by Pseudomonas fluorescens F113 derivatives, using a Sinorhizobium meliloti nod system to drive bph gene expression. Appl Environ Microbiol 71:2687-2694. doi: 10.1128/AEM.71.5.2687-2694.2005

Page 25/32 
Vo-Dinh T, Cullum B (2000) Biosensors and biochips: advances in biological and medical diagnostics. Fresenius J Anal Chem 366:540551. doi: $10.1007 /$ s002160051549

Volk MJ, Lourentzou I, Mishra S, Vo LT, Zhai C, Zhao H (2020) Biosystems Design by Machine Learning. ACS Synthetic Biology. https://doi.org/10.1021/acssynbio.0c00129

Wagner J, Engesser R, Ermes K, Geraths C, Timmer J, Weber W (2019) Synthetic biology-inspired design of signal-amplifying materials systems. Mat Today 22:25-34. https://doi.org/10.1016/j.mattod.2018.04.006

Wan X, Volpetti F, Petrova E, French C, Maerkl J, Wang B (2019) Cascaded amplifying circuits enable ultrasensitive cellular sensors for toxic metals. Nat Chem Biol 15:540-548. https://doi.org/10.1038/s41589-019-0244-3

Wang B, Barahona M, Buck M (2015) Amplification of small molecule-inducible gene expression via tuning of intracellular receptor densities. Nucleic Acids Res 43:1955-1964. doi: 10.1093/nar/gku1388

Wang B, Buck M (2014) Rapid engineering of versatile molecular logic gates using heterologous genetic transcriptional modules. Chem Commun 50:11642-11644. https://doi.org/10.1039/C4CC05264A

Wang B, Kitney I, Joly N, Buck M (2011) Engineering modular and orthogonal genetic logic gates for robust digital-like synthetic biology. Nat Commun 2:508. https://doi.org/10.1038/ncomms1516

Wang D, Zheng Y, Fan X, Xu L, Pang T, Liu T, Liang L, Huang S, Xiao Q (2020) Visual detection of Hg2+ by manipulation of pyocyanin biosynthesis through the Hg2+-dependent transcriptional activator MerR in microbial cells. J. Bioscie. Bioengineer. 129:223-8. https://doi.org/10.1016/j.jbiosc.2019.08.005

Wang, B., Kitney, R.I., Joly, N. and Buck, M., 2011. Engineering modular and orthogonal genetic logic gates for robust digital-like synthetic biology. Nature communications, 2(1), pp.1-9. doi.org/10.1038/ncomms1516

Wang, J., Verbeure, B., Luyten, I., Lescrinier, E., Froeyen, M., Hendrix, C., Rosemeyer, H., Seela, F., Van Aerschot, A. and Herdewijn, P., 2000. Cyclohexene nucleic acids (CeNA): serum stable oligonucleotides that activate RNase $\mathrm{H}$ and increase duplex stability with complementary RNA. Journal of the American Chemical Society, 122(36), pp.8595-8602.

Wei H, Ze-Ling S, Le-Le C, Wen-Hui Z, Chuan-Chao D (2014) Specific detection of bioavailable phenanthrene and mercury by bacterium reporters in the red soil. Int J Environ Sci Technol 11:685-694. doi: 10.1007/s13762-013-0216-1

Welsh S, Kay A (1997) Reporter gene expression for monitoring gene transfer. Curr Opin Biotechnol 8:617-622. https://doi.org/10.1016/S0958-1669(97)80038-9

Wepener V, Van Vuren H, Du Preez H (2001) Uptake and distribution of copper, iron and zinc mixture in gill, liver and plasma of a freshwater teleost, Tilapia sparrmanii. Water SA 27:99-108. doi: 10.4314/wsa.v27i1.5016

Whangsuk W, Thiengmag S, Dubbs J, Mongkolsuk S, Loprasert S (2016) Specific detection of the pesticide chlorpyrifos by a sensitive genetic-based whole cell biosensor. Anal Biochem 493:11-13. doi: 10.1016/j.ab.2015.09.022

Wicke N, Radford S, French E (2018) A simple chromogenic whole-cell arsenic biosensor based on Bacillus subtilis. bioRxiv 395178. doi: https://doi.org/10.1101/395178

Wilkes, R.A. and Aristilde, L., 2017. Degradation and metabolism of synthetic plastics and associated products by Pseudomonas sp.: capabilities and challenges. Journal of applied microbiology, 123(3), pp.582-593. doi.org/10.1111/jam.13472

World Health Organization, 2004, Guidelines for drinking-water quality (Vol. 1). World Health Organization

Wright O, Stan B and Ellis T (2013). Building-in biosafety for synthetic biology. Microbiol 159:1221-1235. doi.org/10.1099/mic.0.066308-0

Wu H, Le D, Mulchandani A, Chen W (2009) Optimization of a whole-cell cadmium sensor with a toggle gene circuit. Biotechnol Prog 25, 898-903. doi: 10.1002/btpr.203

Xing C, Chen J, Zheng X, Chen L, Chen M, Wang L, Li X (2020) Functional metagenomic exploration identifies novel prokaryotic copper resistance genes from the soil microbiome. Metallomics (3):387-95. doi.org/10.1039/C9MT00273A

Page 26/32 
Yan L, Sun P, Xu Y, Zhang S, Wei W, Zhao J (2018) Integration of a gold-specific whole E. coli cell sensing and adsorption based on bioBrick. Int J mol Sci 19:3741. doi: 10.3390/ijms19123741

Yang J, Liu R, Song W, Yang Y, Cui F, Qiao C (2012) Construction of a genetically engineered microorganism that simultaneously degrades organochlorine and organophosphate pesticides. Appl Biochem Biotechnol 166:590-598. doi: 10.1007/s12010-011-9450-5

Yang K, Peretz-Soroka H, Liu Y, Lin F (2016) Novel developments in mobile sensing based on the integration of microfluidic devices and smartphones. Lab on a Chip 16:943-58

Yadav K, Ali S A, Mohanty A K, Muthusamy E, Subaharan K, Kaul, G (2021) MSN, MWCNT and ZnO nanoparticle-induced CHO-K1 cell polarisation is linked to cytoskeleton ablation. Journal of Nanobiotechnology, 19(1), 1-24.

Yoon Y, Kang Y, Chae Y, Kim S, Lee Y, Jeong W, An J (2016) Arsenic bioavailability in soils before and after soil washing: the use of Escherichia coli whole-cell bioreporters. Environ Sci Pollut Res 23:2353-2361. doi: 10.1007/s11356-015-5457-8

Yu S, Qin W, Zhuang G, Zhang X, Chen G, Liu W (2009) Monitoring oxidative stress and DNA damage induced by heavy metals in yeast expressing a redox-sensitive green fluorescent protein. Curr Microbiol 58:504-510. doi: 10.1007/s00284-008-9354-y

Zhang, L., Peritz, A. and Meggers, E., 2005. A simple glycol nucleic acid. Journal of the American Chemical Society, 127(12), pp.4174-4175.

\section{Declarations}

\section{Acknowledgments}

We would also like to thank the Director of the ICAR-National Dairy Research Institute (NDRI), India, for providing the necessary facilities to carry out the research work. The authors received no funding from an external source and have no conflicting interests.

\section{Consent for publication}

The authors gave their consent for publication of the research results.

\section{Tables}

Table 1. Comprehensive list of biosensors used in recent studies for the detection of heavy metals and xenobiotics. 


\begin{tabular}{|c|c|c|c|c|c|c|}
\hline Target analyte & Host strain & $\begin{array}{l}\text { Expression vector/ } \\
\text { sensor }\end{array}$ & $\begin{array}{l}\text { Detection } \\
\text { limit }\end{array}$ & Response time & Sample type & References \\
\hline \multicolumn{7}{|l|}{ Heavy metals } \\
\hline \multirow[t]{10}{*}{ Arsenic } & E. coli BL21 & pET-3a & $5 \mu \mathrm{g} / \mathrm{ml}$ & $15 \min$ & Water & $\begin{array}{l}\text { Shohel et al., } \\
2011\end{array}$ \\
\hline & E. coli & pIRC140 & $1 \mathrm{ppm}$ & $10-12 \mathrm{~h}$ & $\begin{array}{l}\text { Spiked } \\
\text { sample }\end{array}$ & $\begin{array}{l}\text { Roberto et } \\
\text { al., } 2002\end{array}$ \\
\hline & $\begin{array}{l}\text { E. coli } \\
\text { (AW3110) }\end{array}$ & рT0031 & $1-10 \mu \mathrm{M}$ & $90 \min$ & $\begin{array}{l}\text { Spiked water } \\
\text { samples }\end{array}$ & $\begin{array}{l}\text { Tauriainen et } \\
\text { al., } 1999\end{array}$ \\
\hline & F coliDH5a & ars-puc18-yfp & $8 \mu \mathrm{mol} / \mathrm{l}$ & $2 \mathrm{~h}$ & $\begin{array}{l}\text { Spiked } \\
\text { sample }\end{array}$ & $\begin{array}{l}\text { Qing Hu et } \\
\text { al., } 2010\end{array}$ \\
\hline & $\begin{array}{l}\text { Pseudomonas } \\
\text { fluorescens }\end{array}$ & pTPT21 and pTPT31 & $10 \mu \mathrm{M}$ & $2 \mathrm{~h}$ & $\begin{array}{l}\text { Spiked } \\
\text { sampple }\end{array}$ & $\begin{array}{l}\text { Petänen et } \\
\text { al., } 2001\end{array}$ \\
\hline & E. coli JM109 & pSB1A2 & $<5 \mathrm{ppb}$ & $5 \mathrm{~h}$ & Water & $\begin{array}{l}\text { Aleksic et al., } \\
2007\end{array}$ \\
\hline & E. coli K-12 & POLA (VtP)-gfp & $5-140 \mu \mathrm{g} / \mathrm{I}$ & $1 \mathrm{~h}$ & Water & $\begin{array}{l}\text { Pola et al., } \\
2018\end{array}$ \\
\hline & E. coli & $\begin{array}{l}\text { pHg-lux, pAs-lux, pHg- } \\
\text { gfp, pVLAS1 }\end{array}$ & $\begin{array}{l}0.025-0.1 \\
\mu \mathrm{M}\end{array}$ & $2 \mathrm{~h}$ & Sewage water & $\begin{array}{l}\text { Huang et al., } \\
2015\end{array}$ \\
\hline & $\begin{array}{l}\text { Thermus } \\
\text { thermophilus } \\
\text { HB27 }\end{array}$ & $\begin{array}{l}\text { TtArsXpbgaA-nqo } \\
\text { TtSmtB }\end{array}$ & $\begin{array}{l}5 \mu \mathrm{M}, 10 \\
\mu \mathrm{M}\end{array}$ & $16 \mathrm{~h}$ & $\begin{array}{l}\text { Spiked } \\
\text { sample }\end{array}$ & $\begin{array}{l}\text { Antonucci et } \\
\text { al., } 2018\end{array}$ \\
\hline & $\begin{array}{l}\text { E. coli } \\
\text { MG1655 }\end{array}$ & pBR-arsR773 & $10 \mu \mathrm{g} / \mathrm{l}$ & $5 \mathrm{~h}$ & $\begin{array}{l}\text { Spiked } \\
\text { sample }\end{array}$ & $\begin{array}{l}\text { Elcin and } \\
\text { Öktem , } 2020\end{array}$ \\
\hline \multirow[t]{5}{*}{ Cadmium } & E. coli BL21 & $\mathrm{pl} 258$ & $10 \mu \mathrm{g} / \mathrm{l}$ & $30 \min$ & Water & $\begin{array}{l}\text { Shohel et al., } \\
2011\end{array}$ \\
\hline & $\begin{array}{l}\text { S. cerevisiae } \\
\text { Y2805 }\end{array}$ & YEpSSEO-gfp & $300 \mu \mathrm{M}$ & $2 \mathrm{~h}$ & $\begin{array}{l}\text { Spiked } \\
\text { sample }\end{array}$ & $\begin{array}{l}\text { Jeong et al., } \\
2007\end{array}$ \\
\hline & $\begin{array}{l}\text { Pseudomonas, } \\
\text { Shewanella and } \\
\text { Enterobacter }\end{array}$ & pBBcadRgfp-rfp & $\begin{array}{l}0.01-10 \\
\mu \mathrm{g} / \mathrm{ml}\end{array}$ & $20-40 \min$ & Spiked water & $\begin{array}{l}\text { Bereza et al., } \\
2017\end{array}$ \\
\hline & E. coli BL21 & pegfp-N1 & $5 \mu \mathrm{M}$ & $1-2 \mathrm{~h}$ & $\begin{array}{l}\text { Spiked } \\
\text { sample }\end{array}$ & $\begin{array}{l}\text { Lee et al., } \\
2019\end{array}$ \\
\hline & $\begin{array}{l}\text { Thermus } \\
\text { thermophilus } \\
\text { HB27 }\end{array}$ & $\begin{array}{l}\text { TtArsXpbgaA-nqo } \\
\text { TtSmtB }\end{array}$ & $\begin{array}{l}5 \mu \mathrm{M}, 10 \\
\mu \mathrm{M}\end{array}$ & $16 \mathrm{~h}$ & $\begin{array}{l}\text { Spiked } \\
\text { sample }\end{array}$ & $\begin{array}{l}\text { Antonucci et } \\
\text { al., } 2018\end{array}$ \\
\hline \multirow[t]{2}{*}{ Chromium } & $\begin{array}{l}\text { Salmonella } \\
\text { typhimurium } \\
\text { TA1535 }\end{array}$ & pPLS-1 & $\begin{array}{l}0.13 \\
\mathrm{mmol} / \mathrm{l}\end{array}$ & $5 \mathrm{~h}$ & $\begin{array}{l}\text { Spiked } \\
\text { sample }\end{array}$ & $\begin{array}{l}\text { Elke et al., } \\
2002\end{array}$ \\
\hline & $\begin{array}{l}\text { E. coli, } \\
\text { Ochrobactrum } \\
\text { tritici }\end{array}$ & $\begin{array}{l}\text { pCHR-gfp1, pCHR- } \\
\text { gfp2 }\end{array}$ & $\begin{array}{l}0.5-2 \mu \mathrm{M}, 2- \\
10 \mu \mathrm{M}\end{array}$ & $<14$ days & $\begin{array}{l}\text { Artificial and } \\
\text { natural soil }\end{array}$ & $\begin{array}{l}\text { Coelho et al., } \\
2015\end{array}$ \\
\hline
\end{tabular}




\begin{tabular}{|c|c|c|c|c|c|c|}
\hline & $\begin{array}{l}\text { Acinetobacter } \\
\text { baylyi }\end{array}$ & ADP1-RecA-lux & $520 \mathrm{mg} / \mathrm{kg}$ & $6 \mathrm{~h}$ & $\begin{array}{l}\text { Contaminated } \\
\text { soil }\end{array}$ & $\begin{array}{l}\text { Song et al., } \\
2014\end{array}$ \\
\hline \multirow[t]{4}{*}{ Copper } & E. coli $\mathrm{DH} 5 \mathrm{a}$ & $\begin{array}{l}\text { YEp352-FUSI; } \\
\text { pYe(lacZ)1-CUP1 }\end{array}$ & $0.5-2 \mathrm{mM}$ & $15 \mathrm{~min}$ & $\begin{array}{l}\text { Spiked } \\
\text { sample }\end{array}$ & $\begin{array}{l}\text { Lehmann et } \\
\text { al., } 2000\end{array}$ \\
\hline & $\begin{array}{l}\text { E. coli } \mathrm{CB} 454 \text { and } \\
\text { Achromobacter } \\
\text { sp. } \mathrm{AO} 22\end{array}$ & pCOPRP & $\begin{array}{l}0.8 \text { and } 2 \\
\mathrm{nM}\end{array}$ & $\begin{array}{l}2 \mathrm{~h}(\text { E. coli) and } \\
4.5 \mathrm{~h} \\
\text { (Achromobacter) }\end{array}$ & $\begin{array}{l}\text { Spiked } \\
\text { sample }\end{array}$ & $\begin{array}{l}\mathrm{Ng} \text { et al., } \\
2012\end{array}$ \\
\hline & E. coli J53 & pK19mobsacGFP & $20-600 \mu \mathrm{M}$ & $4 \mathrm{~h}$ & $\begin{array}{l}\text { Spiked } \\
\text { sample }\end{array}$ & $\begin{array}{l}\text { Martinez et } \\
\text { al., } 2019\end{array}$ \\
\hline & $\begin{array}{l}\text { Synechococcus } \\
\text { sp. PCC } 7002\end{array}$ & GolS-ypet & $10 \mu \mathrm{M}$ & $1 \mathrm{~h}$ & $\begin{array}{l}\text { Spiked } \\
\text { sample }\end{array}$ & $\begin{array}{l}\text { Lacey et al., } \\
2019\end{array}$ \\
\hline \multirow[t]{7}{*}{ Lead } & $\begin{array}{l}\text { Pseudomonas. } \\
\text { Putida KT2440 }\end{array}$ & $\begin{array}{l}\text { pDN-PcadA1lux } \\
\text { and pDNPczc1lux }\end{array}$ & $0.90 \mu \mathrm{M}$ & & $\begin{array}{l}\text { Spiked } \\
\text { sample }\end{array}$ & $\begin{array}{l}\text { Anu et al., } \\
2010\end{array}$ \\
\hline & $\begin{array}{l}\text { E. coli } \mathrm{DH} 5 \mathrm{a} \\
\text { P. aeruginosa } \\
\text { PAO1 }\end{array}$ & pBBbrR-gfp & $\begin{array}{l}0.2-1 \\
\mu \mathrm{g} / \mathrm{mL}\end{array}$ & $30-100 \mathrm{~min}$ & $\begin{array}{l}\text { Spiked tap } \\
\text { water, } \\
\text { groundwater }\end{array}$ & $\begin{array}{l}\text { Bereza- } \\
\text { Malcom et } \\
\text { al., } 2016\end{array}$ \\
\hline & $\begin{array}{l}\text { S. oneidensis MR- } \\
1\end{array}$ & & & & & \\
\hline & $\begin{array}{l}\text { Enterobacter sp. } \\
\text { NCR3 }\end{array}$ & & & & & \\
\hline & $\begin{array}{l}\text { Enterobacter sp. } \\
\text { LCR17 }\end{array}$ & & & & & \\
\hline & E. coli $\mathrm{DH} 5 a$ & $\begin{array}{l}\text { kan } \triangle \text { pbrA-PpbrRT- } \\
\text { pbrR-luxR } \Delta 2-162\end{array}$ & $5 \mu \mathrm{M}$ & $8 \mathrm{~h}$ & $\begin{array}{l}\text { Contaminated } \\
\text { and Spiked } \\
\text { sample }\end{array}$ & $\begin{array}{l}\text { Jia er al., } \\
2018\end{array}$ \\
\hline & E. coli & pPpbr-RFP-lacZ. & $3 \mu \mathrm{M}$ & $4 \mathrm{~h}$ & $\begin{array}{l}\text { Spiked } \\
\text { sample }\end{array}$ & $\begin{array}{l}\text { Hui et al., } \\
2020\end{array}$ \\
\hline \multirow[t]{6}{*}{ Mercury } & $\begin{array}{l}\text { Pseudomonas } \\
\text { fluorescens }\end{array}$ & рTPT11 & $\begin{array}{l}0.003 \mu \mathrm{g} \\
\mathrm{kg}-1\end{array}$ & $24 \mathrm{~h}$ & Spiked soil & $\begin{array}{l}\text { Petänen et } \\
\text { al., } 2002\end{array}$ \\
\hline & E. coli $\mathrm{DH} 5 \mathrm{a}$ & pPROBE-KT & $0.002 \mathrm{ppm}$ & $16 \mathrm{~h}$ & $\begin{array}{l}\text { Spiked } \\
\text { sample }\end{array}$ & $\begin{array}{l}\text { Gireesh and } \\
\text { Chaudhari, } \\
2012\end{array}$ \\
\hline & $\begin{array}{l}\text { Pseudomonas } \\
\text { putida }\end{array}$ & merR-egfp & $<40 \mu \mathrm{g} / \mathrm{kg}$ & 6 days & Soil & $\begin{array}{l}\text { Wei et al., } \\
2014\end{array}$ \\
\hline & Sphingobium SA2 & merA-gfp & $0-40 \mathrm{nM}$ & $5 \mathrm{~h}$ & Water & $\begin{array}{l}\text { Mahbub et } \\
\text { al., } 2017\end{array}$ \\
\hline & E. coli & $\begin{array}{l}\text { pHg-gfp, pVLAS1, } \\
\text { pHg-lux }\end{array}$ & $\begin{array}{l}0.025-0.1 \\
\mu \mathrm{M}\end{array}$ & $2 \mathrm{~h}$ & Sewage water & $\begin{array}{l}\text { Huang et al., } \\
2015\end{array}$ \\
\hline & E. coli & $\begin{array}{l}\text { pRLucMer19, } \\
\text { pRGfpMer19 }\end{array}$ & $1 \mathrm{ppb}$ & $1 \mathrm{~h}$ & $\begin{array}{l}\text { Spiked } \\
\text { sample }\end{array}$ & $\begin{array}{l}\text { Gupta et al., } \\
2019\end{array}$ \\
\hline \multirow[t]{2}{*}{ Zinc } & $\begin{array}{l}\text { Synechococcus } \\
\text { PCC7942 }\end{array}$ & pJLE23 & $2 \mu \mathrm{M}$ & $4 \mathrm{~h}$ & $\begin{array}{l}\text { Spiked } \\
\text { sample }\end{array}$ & $\begin{array}{l}\text { Erbe et al., } \\
1996\end{array}$ \\
\hline & E. coli & zntA-PzntR-gfp & $0-25 \mathrm{mg} / \mathrm{l}$ & $3 \mathrm{~h}$ & $\begin{array}{l}\text { Liquid media, } \\
\text { soil }\end{array}$ & $\begin{array}{l}\text { Hurdebise et } \\
\text { al., } 2015\end{array}$ \\
\hline
\end{tabular}




\begin{tabular}{|c|c|c|c|c|c|c|}
\hline \multirow[t]{2}{*}{ Gold } & $\begin{array}{l}\text { Synechococcus } \\
\text { sp. PCC } 7002\end{array}$ & GolS-ypet & $100 \mathrm{nM}$ & $1 \mathrm{~h}$ & $\begin{array}{l}\text { Spiked } \\
\text { sample }\end{array}$ & $\begin{array}{l}\text { Lacey et al., } \\
2019\end{array}$ \\
\hline & E. coli $\mathrm{DH} 5 \mathrm{a}$ & pgolB-rfp & $0.1 \mu \mathrm{M}$ & $10 \mathrm{~h}$ & $\begin{array}{l}\text { Spiked } \\
\text { sample }\end{array}$ & $\begin{array}{l}\text { Yan et al., } \\
2018\end{array}$ \\
\hline
\end{tabular}

\section{Other xenobiotics}

\begin{tabular}{|c|c|c|c|c|c|c|}
\hline \multirow[t]{2}{*}{ p-nitrophenol (PNP) } & $\begin{array}{l}\text { Arthrobacter. JS } \\
443 .\end{array}$ & pUTGFP2 & $5 \mathrm{nM}$ & $5 \min$ & & $\begin{array}{l}\text { Lei et al., } \\
2004\end{array}$ \\
\hline & Moraxella sp. & pPNCO33 & $20 \mathrm{nM}$ & $5 \mathrm{~min}$ & $\begin{array}{l}\text { Spiked } \\
\text { sample }\end{array}$ & $\begin{array}{l}\text { Mulchandan } \\
\text { et al., } 2005\end{array}$ \\
\hline $\begin{array}{l}\text { Organophosphate } \\
\text { insecticides }\end{array}$ & $\begin{array}{l}\text { Pseudomonas } \\
\text { putida }\end{array}$ & CDS-pBBR-mpd & $0.2 \mathrm{~g} / \mathrm{l}$ & $24 \mathrm{~h}$ & $\begin{array}{l}\text { Spiked } \\
\text { sample }\end{array}$ & $\begin{array}{l}\text { Liu et al., } \\
2006\end{array}$ \\
\hline
\end{tabular}

\begin{tabular}{|c|c|c|c|c|c|c|}
\hline & E. coli & pET22b & 4 units $/ \mathrm{mL}$ & $8 \mathrm{~h}$ & $\begin{array}{l}\text { Spiked } \\
\text { sample }\end{array}$ & $\begin{array}{l}\text { Kang et al., } \\
2006\end{array}$ \\
\hline & E. coli BL21 (DE3) & $\begin{array}{l}\text { XL1- } \\
\text { Blue/pETLG/pINCM }\end{array}$ & 5 ppm & $8 \mathrm{~h}$ & $\begin{array}{l}\text { Spiked } \\
\text { sample }\end{array}$ & $\begin{array}{l}\text { Yang et al., } \\
2012\end{array}$ \\
\hline \multirow[t]{2}{*}{ Naphthalene } & E. coli DH5a & pRSET-roGFP2 & $\begin{array}{l}1.0 \times 10-4 \\
\text { ppm }\end{array}$ & $2-6 \min$ & $\begin{array}{l}\text { Spiked } \\
\text { sample }\end{array}$ & $\begin{array}{l}\text { Carlos et al., } \\
2010\end{array}$ \\
\hline & Acinetobacter & pWH1274-lux & $0.01 \mu \mathrm{M}$ & $<6 \mathrm{~h}$ & $\begin{array}{l}\text { Groundwater, } \\
\text { soil }\end{array}$ & $\begin{array}{l}\text { Sun et al., } \\
2017\end{array}$ \\
\hline Hydrogen peroxide & $\begin{array}{l}\text { Saccharomyces } \\
\text { cerevisiae }\end{array}$ & roGFP1-R12 & $10 \mathrm{mM}$ & - & $\begin{array}{l}\text { Spiked } \\
\text { sample }\end{array}$ & $\begin{array}{l}\text { Yu et al., } \\
2009\end{array}$ \\
\hline $\begin{array}{l}\text { Polychlorinated } \\
\text { biphenyls (PCB) }\end{array}$ & $\begin{array}{l}\text { Pseudomonas } \\
\text { fluorescens } \\
\text { F113L::1180-GFP }\end{array}$ & pJBA26 & $\begin{array}{l}0.09-1.48 \\
\mathrm{nmol} / \mathrm{mg} \\
\text { of } \\
\text { protein/min }\end{array}$ & $60 \mathrm{~min}$ & $\begin{array}{l}\text { Spiked } \\
\text { sample }\end{array}$ & $\begin{array}{l}\text { Villacieros et } \\
\text { al., } 2005\end{array}$ \\
\hline
\end{tabular}

\begin{tabular}{|c|c|c|c|c|c|c|}
\hline Aromatic pollutant & Pseudomonas sp. & $\begin{array}{l}\text { dnaKp- } \\
\text { DJ::luxCDABE }\end{array}$ & $1 \mathrm{mM}$ & $80 \min$ & $\begin{array}{l}\text { Spiked } \\
\text { sample }\end{array}$ & $\begin{array}{l}\text { Park et al., } \\
2002\end{array}$ \\
\hline
\end{tabular}

\begin{tabular}{|c|c|c|c|c|c|c|}
\hline & $\begin{array}{l}\text { Pseudomonas sp. } \\
\text { DJ-12 }\end{array}$ & pcbCp::IuxCDABE & $0.1 \mathrm{mM}$ & $10 \mathrm{~min}$ & $\begin{array}{l}\text { Spiked } \\
\text { sample }\end{array}$ & $\begin{array}{l}\text { Park et al., } \\
2004\end{array}$ \\
\hline Herbicides & $\begin{array}{l}\text { Synechocystis sp. } \\
\text { strain } \\
\text { PCC6803 }\end{array}$ & pTLUC & $\begin{array}{l}7.47 \mathrm{mg} / \mathrm{l} \\
\text { (urea- } \\
\text { based) }\end{array}$ & $30 \mathrm{~min}$ & $\begin{array}{l}\text { Spiked } \\
\text { sample }\end{array}$ & $\begin{array}{l}\text { Shao et al., } \\
2002\end{array}$ \\
\hline $\begin{array}{l}\text { 2,4-dinitrotoluene } \\
\text { (DNT) }\end{array}$ & E.coli & yqjF-lux & $100 \mu \mathrm{M}$ & $60 \mathrm{~min}$ & Soil & $\begin{array}{l}\text { Kroll et al., } \\
2014\end{array}$ \\
\hline
\end{tabular}




\begin{tabular}{|c|c|c|c|c|c|c|}
\hline & E. coli $\mathrm{DH} 5 \mathrm{a}$ & yqjf-gfp & $4 \mathrm{mg} / \mathrm{L}$ & $\nabla 4 \mathrm{~h}$ & Soil & $\begin{array}{l}\text { Kabessa et } \\
\text { al., } 2016\end{array}$ \\
\hline $\begin{array}{l}\text { 2,4,6- } \\
\text { trinitrotoluene(TNT) }\end{array}$ & E. coli & ybiJ-lux & $148 \mu \mathrm{M}$ & $60 \mathrm{~min}$ & Soil & $\begin{array}{l}\text { Kroll et al., } \\
2014\end{array}$ \\
\hline Phenanthrene & P. putida & phnS-lux & $<10 \mathrm{mg} / \mathrm{kg}$ & 6 days & Soil & $\begin{array}{l}\text { Wei et al., } \\
2014\end{array}$ \\
\hline $\begin{array}{l}\text { Atrazine, cyanuric } \\
\text { acid }\end{array}$ & $\begin{array}{l}\text { E. coli SM004, E. } \\
\text { coli SM003 }\end{array}$ & pBBluxPatzD & $\begin{array}{l}7.83,1.08 \\
\mu \mathrm{M}\end{array}$ & $<4 \mathrm{~h}$ & $\begin{array}{l}\text { Spiked } \\
\text { sample }\end{array}$ & $\begin{array}{l}\text { Hua et al., } \\
2015\end{array}$ \\
\hline 2-nitrobenzoate & $\begin{array}{l}\text { Cupriavidus sp. } \\
\text { ST-14 }\end{array}$ & onb-egfp & $\begin{array}{l}0.5 \mathrm{nM}-10 \\
\mathrm{mM}\end{array}$ & $1 \mathrm{~h}$ & $\begin{array}{l}\text { Spiked } \\
\text { sample }\end{array}$ & $\begin{array}{l}\text { Deb et al., } \\
2018\end{array}$ \\
\hline n-alkanes & E. coli & PakB-gfp & $5 \mu \mathrm{M}$ & $1-3 h$ & $\begin{array}{l}\text { Spiked } \\
\text { sample }\end{array}$ & $\begin{array}{l}\text { Sevilla et al., } \\
2015\end{array}$ \\
\hline Toxic substances & $\begin{array}{l}\text { Vibrio } \\
\text { aquamarines } \\
\text { VPKM B-11245, E. } \\
\text { coli MG } 1655\end{array}$ & $\begin{array}{l}\text { pRecA-lux, pKatG- } \\
\text { lux, pSoxS-lux, } \\
\text { plbpA-lux, pFabA- } \\
\text { lux }\end{array}$ & & & $\begin{array}{l}\text { Contaminated } \\
\text { wastewater }\end{array}$ & $\begin{array}{l}\text { Sazykin et } \\
\text { al., } 2016\end{array}$ \\
\hline $\begin{array}{l}\text { Mitomycin C, } \\
\text { benzo[a]pyrene }\end{array}$ & $\begin{array}{l}\text { Acinetobacter } \\
\text { baylyi }\end{array}$ & ADP1_recA_lux & $\begin{array}{l}0.4 \mathrm{mg} / \mathrm{kg} \\
0.5 \mathrm{mg} / \mathrm{kg}\end{array}$ & $6 \mathrm{~h}$ & $\begin{array}{l}\text { Contaminated } \\
\text { soil }\end{array}$ & $\begin{array}{l}\text { Song et al., } \\
2014\end{array}$ \\
\hline
\end{tabular}

\section{Figures}




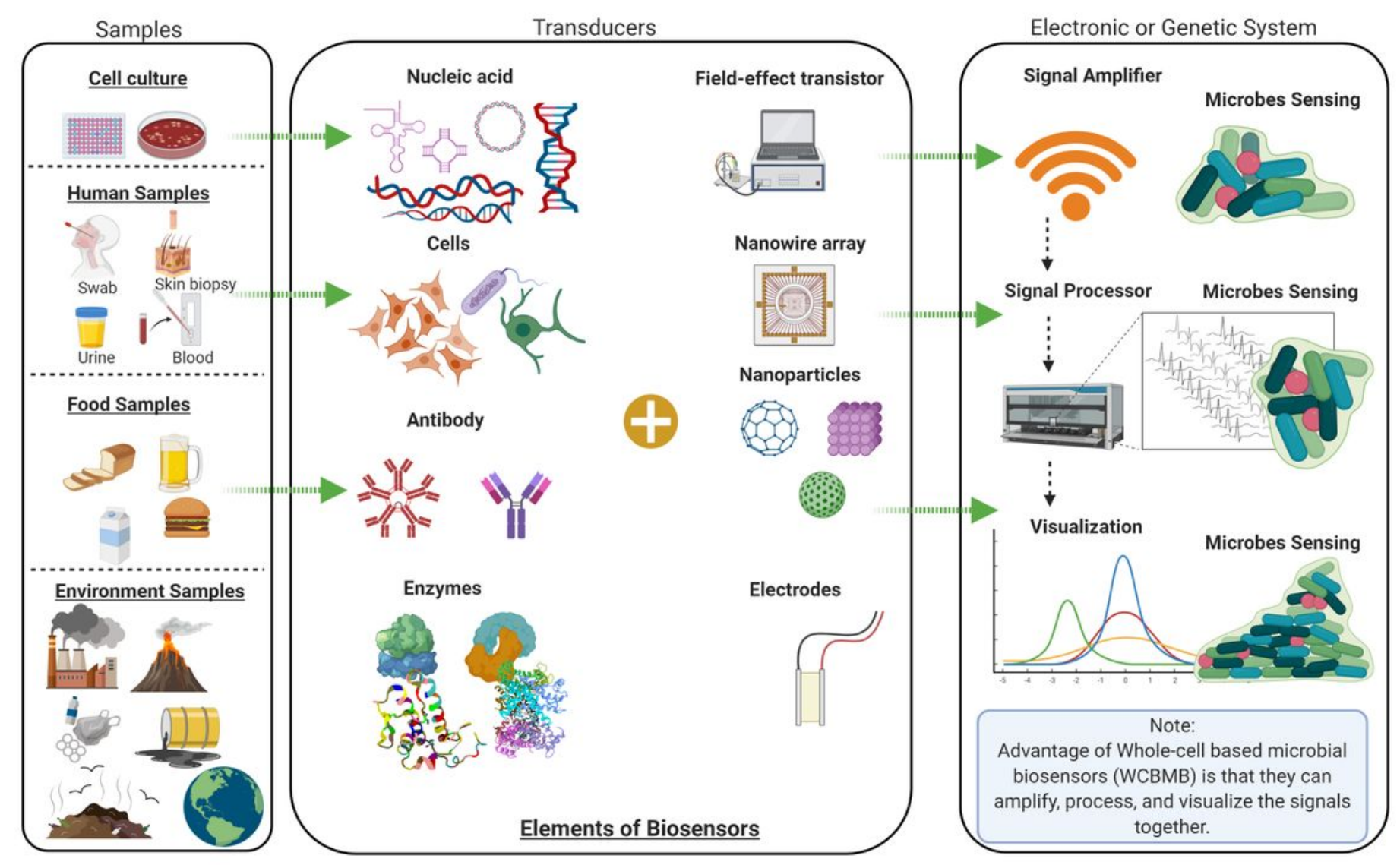

Figure 1

Comprehensive overview of elements of biosensors. 